DEMOGRAPHIC RESEARCH

VOLUME 33, ARTICLE 42, PAGES 1165-1210

PUBLISHED 4 DECEMBER 2015

http://www.demographic-research.org/Volumes/Vol33/42/

DOI: 10.4054/DemRes.2015.33.42

Research Article

Mother's educational level and single motherhood:

Comparing Spain and Italy

Anna Garriga

Sebastià Sarasa

Paolo Berta

(c) 2015 Anna Garriga, Sebastià Sarasa \& Paolo Berta.

This open-access work is published under the terms of the Creative Commons Attribution NonCommercial License 2.0 Germany, which permits use, reproduction \& distribution in any medium for non-commercial purposes, provided the original author(s) and source are given credit.

See http:// creativecommons.org/licenses/by-nc/2.0/de/ 


\section{Table of Contents}

1 Introduction 1166

2 The Second Demographic Transition and educational variation in 1167 single parenthood

$3 \quad$ Different trends in Italy and Spain 1169

$4 \quad$ Data and methods $\quad 1175$

4.1 Analytical plan 1175

$\begin{array}{lll}4.2 & \text { Data } & 1177\end{array}$

$\begin{array}{lll}4.3 & \text { Variables } & 1178\end{array}$

4.3.1 Variables 1178

$\begin{array}{lll}\text { 4.3.2 } & \text { Independent variables } & 1180\end{array}$

5 Results 1182

5.1 What are the main characteristics of Spanish and Italian single 1182

5.2 Does the effect of mother's educational level on single motherhood 1185

$\begin{array}{lll} & \text { differ between Spain and Italy? } \\ 5.3 & \text { Does the main effect of educational level diverge by other } & 1189\end{array}$

$\begin{array}{lll}5.4 & \text { Robustness checks } & 1196\end{array}$

6 Discussion 1197

$\begin{array}{lll}7 & \text { Acknowledgements } & 1198\end{array}$

$\begin{array}{ll}\text { References } & 1200\end{array}$

$\begin{array}{ll}\text { Appendix } & 1206\end{array}$ 


\title{
Mother's educational level and single motherhood: Comparing Spain and Italy
}

\author{
Anna Garriga ${ }^{1}$ \\ Sebastià Sarasa ${ }^{2}$ \\ Paolo Berta ${ }^{3}$
}

\begin{abstract}
BACKGROUND

During the second half of the 20th century there was a positive relationship between single parenthood and the mother's educational level in Spain and Italy.

\section{OBJECTIVES}

However, several important transformations contemplated by Goode (1993) and McLanahan (2004) suggest that this relationship may have been inverted in Spain but perhaps not in Italy. The purpose of our study is to test this hypothesis.
\end{abstract}

\section{METHODS}

We used EU-SILC data from waves 2005 and 2011 and logistic regressions.

\section{RESULTS}

We found the relationship between the mother's educational level and being a single mother is negative in Spain, while it is not significant in Italy. However, we found that for Italian mothers aged 40 and younger and mothers from northwest Italy, this relationship is also negative. By contrast, for older mothers and mothers from the islands or southern Italy, this association is positive. Meanwhile, for mothers from the central and northeast regions, the relationship between educational level and single motherhood is not significant.

\section{CONCLUSIONS}

These results show how Spain and some parts of Italian society are moving towards family models similar to those in the Northern European countries. As Sara McLanahan (2004) noted for the United States, this social transformation in Southern Europe cannot be considered without recognizing the potential negative consequence for future

\footnotetext{
${ }^{1}$ University Pompeu Fabra, Spain. E-Mail: anna.garriga@upf.edu.

${ }^{2}$ University Pompeu Fabra, Spain.

${ }^{3}$ University of Milan - Bicocca, Italy.
} 
generations. The single-mother households dealing with the economic crisis that started in 2008 have lower socioeconomic backgrounds than the single mothers who suffered through previous crises, and therefore the consequences of this crisis for children in single-parent families might be even more negative, especially in Spain.

\section{Introduction}

On average, $15 \%$ of European children live in one-parent households, most of them headed by women, and this kind of household has a higher risk of poverty than coupleheaded households (OECD 2014). Furthermore, there is evidence that under some conditions, nurturing children in single-mother households has negative consequences for the children's cognitive and emotional development that affect them throughout their entire lives (see Sigle-Rushton and McLanahan 2004 for a review). In Southern

European countries, described as family-based welfare regimes (Esping-Andersen 1999), state protection for children is among the lowest in the European Union. However, when comparing poverty ratios between children nurtured in single-parent families and those in two parent households, family-based regimes show smaller differences than other welfare regimes. In the mid-1990s the risk of poverty among children residing in single-parent families was as much as twice as high as the risk of poverty among children residing in two-parent households, while this ratio was much higher in the other Western nations (Luxembourg Income Study, Key Figures. Data from mid-1990's)

It seems paradoxical that the relative standard of living of children in single-parent households is better where state social investment is lower. However, this ceases to be such a paradox when we take into consideration the composition effect of single parenthood in Southern Europe. Previous studies with data from the 1990s or early 2000s showed a positive relationship between single motherhood and educational level in Southern Europe (Flaquer, Almeda, and Navarro 2006; Garriga 2010; McLanahan 2004), while this relationship was negative in Northern Europe (McLanahan 2004; Kennedy and Thomson 2010). Furthermore, a high percentage of single mothers in Southern Europe live with their parents in order to balance work and family life or escape from poverty (Treviño 2006; Flaquer and Garriga 2009).

The purpose of our study is to examine whether such a composition effect still exists in Southern Europe, given the changing social context characterized by: a) a dramatic change in labor market conditions, b) huge changes in the ethnic composition of the younger population as a result of massive immigration waves, and c) deep-seated changes in family values affecting divorce, cohabitation, and out-of-wedlock patterns. 
Given that all these changes have not happened with equal intensity among all southern countries, we have selected Spain and Italy as two cases representing two different trends (Moreno and Marí-Klose 2013). Our results confirm that the relationship between educational level and single parenthood has been clearly inverted in Spain, where we have observed a positive association between less-educated women and single motherhood, where the risk of becoming a single mother is now higher among the less-educated. Similar changes, though lower in intensity, are happening in Italy among younger women and in the wealthiest regions. All in all, these changes seem more related to long-term trends than to any effect derived from the economic crisis or migration.

\section{The Second Demographic Transition and educational variation in single parenthood}

Single parenthood arises from widowhood, out-of-wedlock birth, divorce, and remarriage. Single parenthood is an option for very young girls who get pregnant out of wedlock, most of them from working-class or underclass backgrounds (Kearney and Levine 2012). This source of single parenthood is more frequent in the American continent than in Western Europe, with the exception of the United Kingdom and Ireland, and is very rare in Southern Europe (Part et al. 2013). Widowhood is another source of single parenthood, and for a long time it was the main cause of single parenthood in societies where divorce was forbidden or tightly restricted by law, such as in pre-democratic Spain (Flaquer 1998). Widowhood is more frequent among the lower social strata, given their shorter life expectancy. Hence, the proportion of widows is larger in countries where single parents are older, and the prevalence of unmarried single parents is higher in countries where single parents are younger (Pailhé et al. 2014). However, in most European countries, divorced or separated individuals make up the bulk of one-parent households. About $20 \%$ of single parents are widowed, and another $20 \%$ are 'accidental' or have chosen single motherhood. Therefore, changes in the social distribution of divorce and separation are crucial for understanding the social distribution of single parenthood.

Several studies have analyzed the relationship between female education and family instability and divorce (see, for a review, Bernardi and Martínez-Pastor 2011). It has been demonstrated that in countries and cohorts where the percentage of divorce is low, the relationship between divorce and educational level is positive, and when divorce becomes more common the educational gradient is negative (see Chan and Halpin 2008; Härkönen and Dronkers 2006). This change in the relationship between educational level and divorce was predicted 50 years ago by William Goode (Goode 
1993), who developed a model of the spread of divorce that has received important empirical confirmation. He argued that the relationship between class and family instability depends on the extent to which divorce has become easy to obtain and widespread. When social and economic barriers to divorce are high and divorce is rare it is more common in higher social strata for economic reasons, and because wealthier people have the cultural means to free themselves from the normative pressure to remain married (Blossfeld et al. 1995). By contrast, when economic, social, and legal barriers to divorce fall, the relationship quality comes to the fore as the key determinant of divorce. Given that economic difficulties are key sources of difficult relationships, marital instability becomes more frequent among lower classes (Goode 1951). Hence, when normative restrictions are weak and economic prosperity reduces the economic costs of divorce, divorce becomes closer to a 'commodity' that everyone may consume. Conversely, during economic downturns, the lack of employment deters divorce, especially among lower social classes, in spite of its negative effects on the quality of marital relationships.

The nature and social composition of single parenthood change as the second demographic transition expands. The second demographic transition has been characterized as a set of processes leading to delays in fertility and marriage, greater maternal employment, and increases in single parenthood caused by out-of-wedlock births and the dissolution of unions (Lesthaeghe 1995). The majority of the out-ofwedlock births in the European Union come from cohabiting couples, and cohabiting couples have higher probabilities of dissolution (Kiernan 2004). Kennedy and Thomson (2010) find that the negative gradient of educational level on the risk of parental separation is greater among unmarried than married couples. Accordingly, any change in the educational gradient of single motherhood could be explained by a previous change in the composition of the couples' marital status.

McLanahan (2004) suggests that the second demographic transition leads to a polarization in children's futures, depending on the socioeconomic status of the mother. More-educated women gain more maternal resources through delayed childbearing and remaining employed when they become mothers, while less-educated women lose maternal resources, since they are only loosely attached to the labor market, and out-ofwedlock childbearing and single motherhood are more common among them. Hence, inequality in parental resources diverges even more between children from different backgrounds. McLanahan (2004) identifies four causes of this polarization. The first is the development of birth control technologies that lowered the bargaining power of women who wanted to marry. The second is the 'second wave' of the feminist movement that developed among college students from the 1960s onwards, arguing in favor of free divorce and against the stigmatization of cohabitation and single motherhood. The third is changes in labor market conditions, which have both provided 
strong incentives for women to get a college education and enter the labor force and made less-educated men less marriageable. The last cause is the effect of welfare policies, especially of means-tested benefits, since the greater the benefit level the lower the cost of children for poor single mothers, and the higher the income-testing in the benefit the higher the opportunity cost of having a job and marrying. Among these polarization factors, labor market conditions and ideational changes have evolved differently in Southern European countries, and migration flows have also been different in terms of intensity and cultural origins, as we will see below.

But the composition of single motherhood in individual countries also depends on other factors. Any flow of migrants with different patterns of family formation and dissolution related to the country of origin could affect the relationship between educational level and family structure. On the other hand, several studies show that there is an intergenerational transmission of family structure (Dronkers and Härkönen 2008; Musick and Mare 2006), and that women nurtured in highly educated families have been socialized in liberal values and norms and are therefore more likely to be single mothers (Lyngstad 2006; Schröder 2006). Furthermore, the likelihood of single motherhood varies by place of residence depending on the degree of urbanization and 'modernization'. Divorce and cohabitation are more common in urban areas than in rural areas since the values in cities are more individualistic and there is less stigma attached to new family forms (Jalovaara 2001; Snyder, Brown, and Condo 2004). It is therefore reasonable to assume that single mothers are more urban than rural, and that the change in the educational gradient happens first in urban contexts and then in rural settings. It may be that in rural areas, only mothers with sufficient economic resources are able to deal with the social stigma associated with single motherhood. Finally, the association between remarriage and social class is part and parcel of the bifurcation of children's destinies, as argued by McLanahan (2004); and most research during the 1980s and 1990s, as reviewed by De Graaf and Kalmijn (2003), showed negative or insignificant effects of educational level on remarrying.

\section{Different trends in Italy and Spain}

Economic growth and labor market transformations in Southern Europe during the 1990s and the first decade of the 21st century have gone in the same direction as in other postindustrial societies. Some of these trends are compatible with the variables identified by McLanahan (2004) as change factors in the distribution of single parenthood among social strata: increasing shares of employed women and of women attending college, together with a deterioration in the employability of men with low educational levels; and cultural changes favorable to destigmatization of single 
parenthood and out-of-wedlock births. Furthermore, assuming that divorce may also be a consumption good (Goode 1993), the period of prosperity from the 1990s to 2007 lowered divorce costs for the well-off, thus increasing the likelihood of single parenthood among women with low educational levels.

However, these changes have occurred more intensively in Spain, where economic growth doubled the GDP per inhabitant as well as the number of employed women between 1995 and 2007, while this growth was slower in Italy (46\% rise in GDP per inhabitant and 30\% of women employed). Focusing on women aged 25 to 54 years, Figure 1 shows how the employment rate in Spain has risen so fast that it has overtaken the rate in Italy.

Figure 1: Employment rates among women aged 25 to 54, 1995-2011

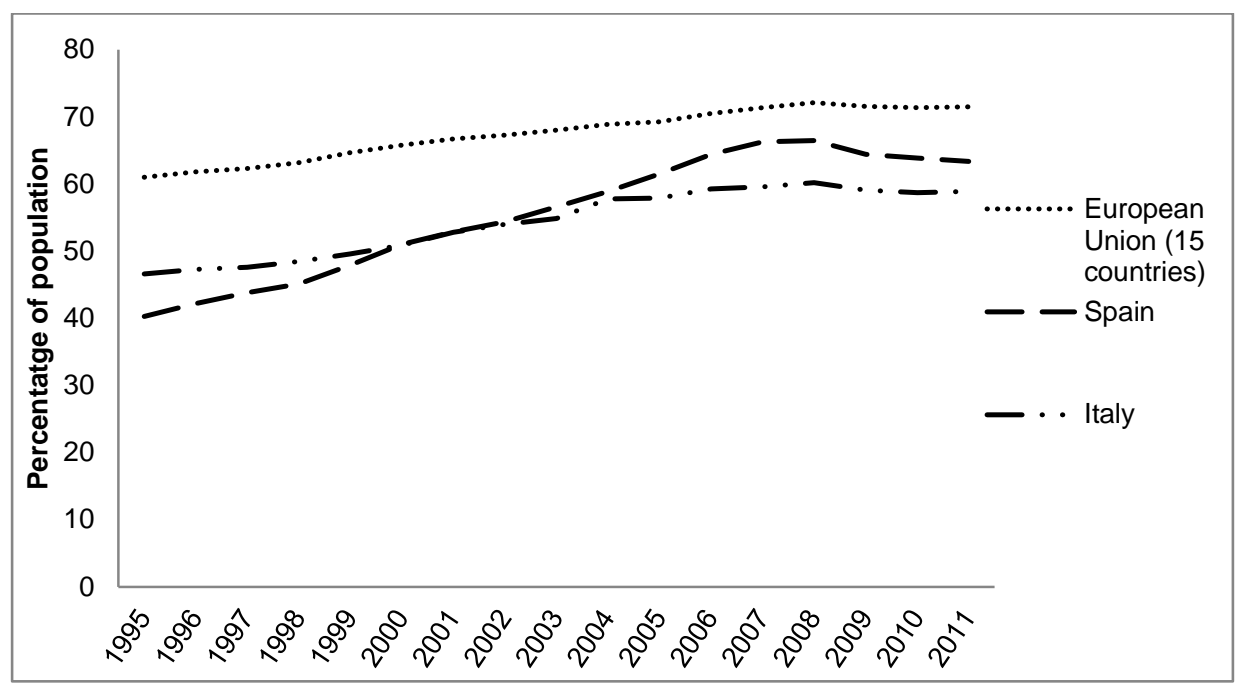

Source: Eurostat.

Both countries increased their share of young women with tertiary education, although Spain has kept its share higher than the European Union average (15 member states) (see Figure 2). 
Figure 2: $\quad$ Women aged 25 to 34 with tertiary education

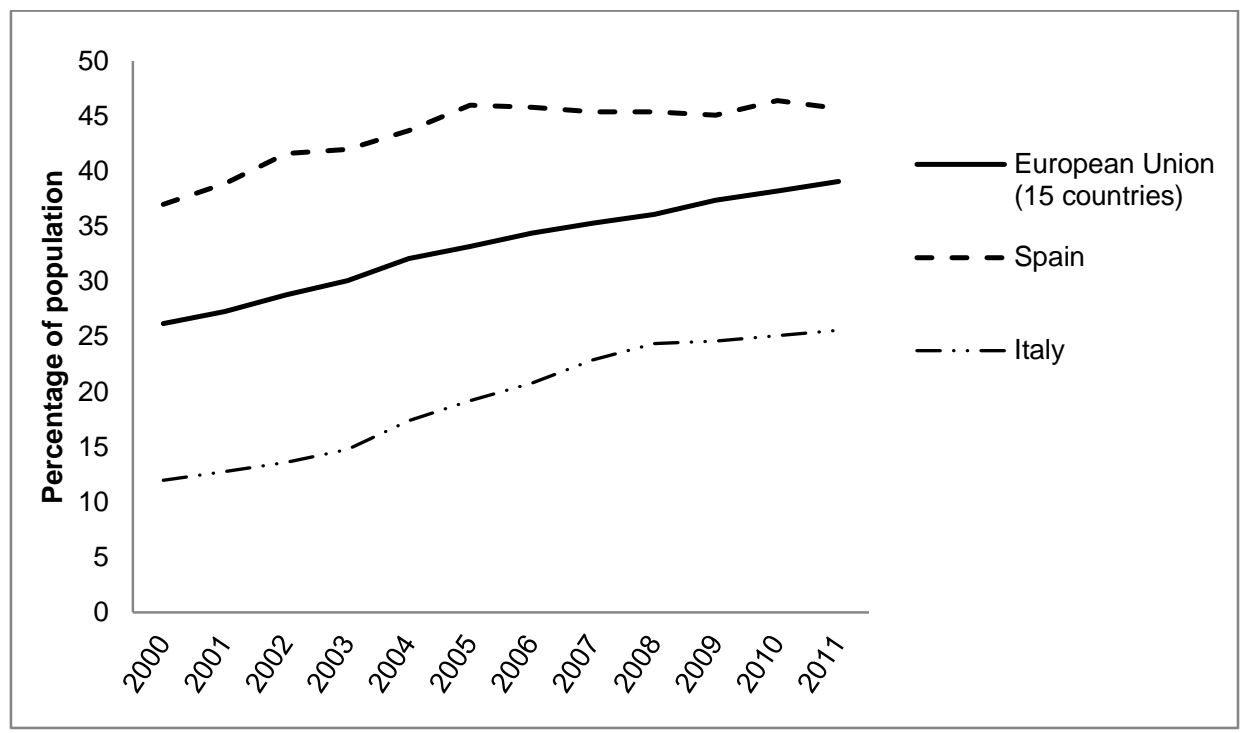

Source: Eurostat.

However, these advances in women's opportunities have been accompanied by stagnation and even a decrease in the employment opportunities for men with lower educational levels, rendering them less marriageable, especially in Spain, where the average employment rate during this period was lower than in Italy (see Figure 3). 
Figure 3: Employment rates among men aged 25 to 54 with lower secondary education or less

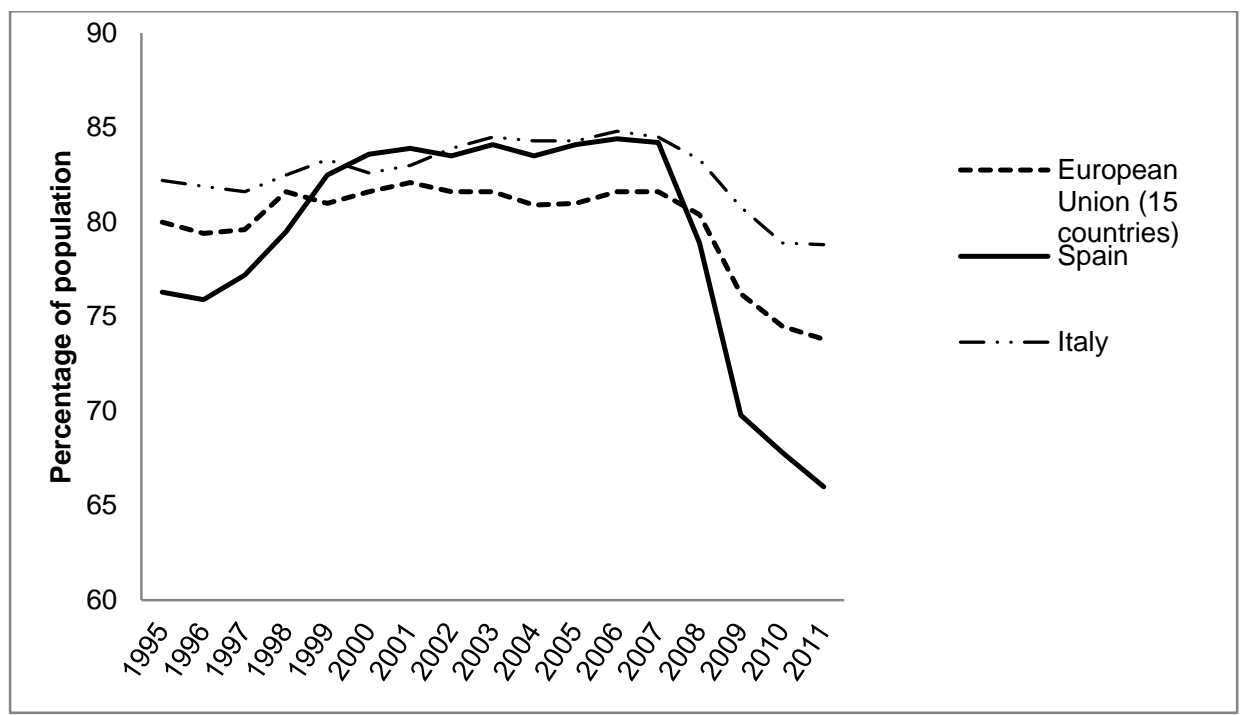

Source: Eurostat

This disparity between Italy and Spain in labor market opportunities for men and women has come hand-in-hand with differences in attitudes and behaviors towards new forms of the family that are related to single parenthood. Research on attitudes towards new forms of the family show that the percentage of respondents who disapprove of single motherhood is substantially lower in Spain than in Italy, and that this percentage in fact increased in Italy between 1990 (43.2\%) and 2008 (54.8\%), while in Spain it decreased over the same period (23.4\% in 1990 and 14\% in 2008) (Moreno and MaríKlose 2013). At the same time, the acceptance of divorce has increased substantially over the last 10 years in Spain (Becerril 2008). Using the 2008 European Values Survey, Moreno and Marí-Klose (2013) show that most Spanish youth (58.3\%) believe that divorce is acceptable always or in most cases, while this percentage was only 23.9\% among Italian youth in 2008.

However, the historical period may affect single motherhood through two mechanisms working in opposite directions. First, the rising share of single mothers in recent decades in both Spain and Italy (Treviño 2006; Istat 2010b) is consistent with the diffusion theory (Goode 1993; McLanahan 2004), for the bulk of single-motherhood in both countries is due to divorce. Hence, the association between educational level and single motherhood is expected to be more negative in Spain than in in Italy, since both 
the divorce rate and all the factors affecting the distribution of single-motherhood among social strata have increased faster in Spain. Second, between the two surveys there was a dramatic about-face in the economic cycle, which increased the costs of single motherhood and divorce, especially for less-educated women. Thus, because the economic crisis has been deeper in Spain, the diffusion effects may be more restrained in that country. At the same time, the higher cost of single motherhood associated with the economic crisis may also lead mothers to leave single motherhood via repartnering, especially among those with lower educational levels (Treviño and Gumà 2013).

Welfare benefits, one of the causal factors hypothesized by McLanahan (2004), are greater in Italy than in Spain. The Spanish welfare state provides lower coverage of single-mother benefits than the Italian system. Furthermore, both countries differ in relation to the redistributive effects of these benefits. Child and family allowances, together with social assistance and housing benefits, are less common among women with low educational levels in Spain than in Italy. ${ }^{4}$

Research on the patterns and evolution of more secularized standards of union formation and dissolution show how Spain is becoming an outlier among Southern European countries and is moving towards family models similar to the Northern European countries (Moreno and Marie-Klose 2013). Though the spread of cohabitation among younger cohorts has been slower in Spain than in other countries (DominguezFolgueras and Castro-Martín 2013), it has increased faster in Spain than in Italy (Dominguez-Folgueras 2013). In Spain, the percentage of births to unwed mothers rose significantly, from 3.9\% in 1980 to 35\% in 2010; most of them occurred in cohabiting couples (Dominguez-Folgueras and Castro-Martín 2013). By contrast, the number of cohabiting women with children is extremely low in Italy (Creighton et al. 2013). These differences in cohabitation between the two countries are relevant, given the higher risk of union dissolution among cohabiting couples (Kiernan 2004). Furthermore, the group that has chosen single motherhood through adoption is growing in countries where single parents can adopt, such as Spain (Pailhé et al. 2014).

With regard to divorce, Spain and Italy have experienced a similar secular evolution (see Matysiak, Styrc, and Vignoli 2014). These countries represent the Mediterranean model, which is characterized by a very low level of social protection, strong family relationships, and traditional values (e.g., Reher 1998). Both countries approved their divorce laws later than most other European countries (Italy in $1970^{5}$

\footnotetext{
${ }^{4}$ Child and family allowances, together with social assistance and housing benefits, cover $53 \%$ of Italian single-mother households but only $12 \%$ in Spain. Furthermore, in terms of redistribution, benefits are regressive in Spain, because the coverage is higher (17\%) among single mothers with tertiary education, albeit still lower than in Italy (43\% of single mothers with higher education). Authors' estimates based on EU-SILC 2011.

${ }^{5}$ Law of 1 December 1970, No. 898 (La legge Fortuna-Baslini).
} 
and Spain in $1981^{6}$ ). However, though in 1990 the Spanish and Italian divorce rates were very similar and lower than in other developed countries, by 2010 the Spanish divorce rate was much higher and more similar to Austria, Germany, or Norway than to Italy (Creighton et al. 2013). The most important increases have occurred since 2000. In 2005, Spain's divorce law ${ }^{7}$ changed from being one of the most restrictive in the world to being one of the most liberal, while Italian divorce law has not changed and remains one of the most restrictive in the world.

Studies of the relationship between educational level and divorce suggest that during the 1980s and the beginning of the 1990s the relationship between educational level and divorce was positive and the gradient of marital disruption gradually weakened (Bernardi and Martínez-Pastor 2011; Gabrielli and Vignoli 2013). Nevertheless, in their meta-analysis of the relationship between educational level and divorce, Matysiak, Styrc, and Vignoli (2014) show that in the most recent studies of both countries the positive educational gradient has changed. However, it is important to note that neither of these recent studies on the relationship between divorce and educational level uses data that has been collected in the last eight years, and there have been several important transformations in Spain that suggest that Spain and Italy might no longer be following the same pattern.

Repartnering patterns also appear to be different in Spain than in Italy. No significant association between repartnering and educational level has been found in Italy (Meggiolaro and Ongaro 2008). But in Spain today, immigrant women and women with lower educational levels are more likely to leave single motherhood (Treviño and Gumà 2013). Although repartnering can provide an additional income earner in the household and is the "surest path to economic recovery" after divorce (Smock, Manning, and Gupta 1999: 807), during times of uncertainty, such as the economic recession which started in 2008, more-educated women might have higher chances of marrying and remarrying than poorer mothers (Oppenheimer 1988, 1994). Likewise, a recent analysis of Spanish data confirms that the educational gradient in favor of the repartnering of women with lower educational levels was weakening in 2010 (Treviño and Gumà 2013).

The economic growth cycle, together with the EU integration process, changed the migration flows in Southern Europe, attracting people from parts of the world with heterogeneous family values. Hence, the sociodemographic and cultural composition of women in both countries has changed in different ways as a result of massive waves of immigration that have multiplied the number of foreign-born inhabitants in Spain by 8.7

\footnotetext{
${ }^{6}$ Law of 7 July 1981,. No. 30.

${ }^{7}$ Law of 8 July 1981,. No. 15.
} 
between 1998 and 2011, while this figure was 4.6 in Italy. ${ }^{8}$ Spain has had a higher influx of immigrants from Latin America (approximately $40 \%$ of total immigrants) (Muñoz de Bustillo and Anton 2010; Spanish Institute of Statistics 2011), while in Italy most non-EU immigrants come from Morocco, Albania, or China (Istat 2013). Immigrants from Latin America show a higher proportion of households led by single mothers compared to immigrants from Africa or Asia (Domingo and Parnau 2006). For these reasons, it is plausible to expect that the mothers born in non-European countries are more likely to be single mothers in Spain, while we do not hypothesize these same differences for Italy. Esteve, García-Román, and Lestahaeghe (2012) also show that among women aged 25-29, the higher the educational level the lower the incidence of single motherhood in most Latin American countries. In fact, the percentage of single motherhood in these countries (Esteve, García-Román, and Lestahaeghe 2012) is higher than the percentages of single motherhood that we found in Italy and Spain (see Table 1).

All the reasons outlined above make a change in the relationship between single motherhood and social status likely, but with differing intensities in Spain and Italy. In this paper we hypothesize that during the last decade the relationship between single motherhood and educational level has become negative in Spain, while this change has not yet happened in Italy.

\section{Data and methods}

\subsection{Analytical plan}

To test our hypothesis, we selected a sample of households from the EU-SILC 2005 and 2011 composed of at least a mother and one or more children younger than 18 living together. We have restricted the children's age interval because people younger than 18 are rarely emancipated, and this allows us to work with a sample that is unbiased by selection effects because emancipation is not randomly distributed. First, we tested our hypothesis that the mother's educational level is negatively related to single motherhood in Spain, while in Italy this relationship is positive. The effects were estimated specifying a logistic model where single motherhood was adjusted by other factors associated with single motherhood, such as region, degree of urbanization,

\footnotetext{
${ }^{8}$ Data extracted from Eurostat Database, updated on April 10th, 2014.
} 
country of birth, mother's age and marital status, number of children at home ${ }^{9}$, year of the survey, structure of the mother's family of origin, and educational level and labor status of the grandmother.

In the second step, we tried to identify who is pioneering the changes in the association between educational level and the likelihood of single motherhood. Some factors may be contextual, such as place of residence and historical period, while others are socio-demographic, such as country of birth, marital status, and age. Mother's age is negatively related to single-parent families, because young mothers have had less time to experience family disruption or be pregnant outside a stable relationship (Treviño 2006). However, some studies that follow a life-course trajectory show that single motherhood is more common among young cohorts (see for example Treviño 2006). It is plausible that the shift in the relationship between educational level and single motherhood hypothesized in this paper started among young women, because they have fewer social and economic barriers to overcome. Young mothers have more liberal values and greater chances of being employed, since the employment rate is higher among young female cohorts (Moreno and Marí-Klose 2013).

In both countries, there are major economic and social differences between regions along with substantial regional variations in the percentage of single-parent families (Spanish Institute of Statistics 2013a; Istat 2010a). Consequently, we expect the relationship between educational level and single motherhood to be more negative in more urbanized and developed regions.

Considering that teenage motherhood is rare in Spain and Italy (Part 2013), it is reasonable to assume that in these countries never-married single mothers are mainly the result of separations between cohabiting couples. Considering also the high percentage in Spain of immigrants from Latin America, it is reasonable to predict that the negative relationship between educational level and single motherhood will be greater among Spanish non-European mothers than among Spanish mothers, while no differences are expected for Italy.

Given the intergenerational transmission of family structure, it is expected that the structure of the mother's family of origin at age 14 will be positively associated with the probability of being a single-mother family. Hence, given the strong intergenerational transmission of education (Breen and Jonsson 2005), biased estimators of the effects of the mother's educational level are expected if the grandmother's educational level is not controlled for. This bias may be worrisome when the effects of educational level on the likelihood of single motherhood changes its sign

\footnotetext{
${ }^{9}$ Single mothers tend to have fewer children than mothers in two-parent families, since the former have had less time to live in a couple and have more children (Treviño 2006). Therefore, the number of children will be negatively associated with the probability of being a single mother.
} 
between generations, as we suppose has happened in Spain. A strong positive association between the grandmother's higher education and single motherhood may conceal a weak negative association between the daughter's higher education and single motherhood. We cannot introduce the mother's labor status in the model because of its high correlation with educational level and single motherhood in Spain and Italy (Garriga 2010), but we may control it indirectly through the effect of the grandmother's labor status, since the mother's labor status is positively associated with the daughter's labor status (Moen, Erickson, and Dempster-McClain 1997; Farré and Vella 2013).

\subsection{Data}

One of the main problems in studying Spain is the lack of appropriate demographic databases, and this is even more problematic if the aim of the study is to compare Spain with another country. In this paper we were unable to use the Gender Generation Survey ${ }^{10}$, which is one of the best comparative European surveys for studying family formation from an international perspective, because even though Italy is included in the sample, Spain is not. ${ }^{11}$ For this reason, and despite its limitations, we used the EU-SILC database, as the only database that contains Spanish data on the characteristics of single-mother families in recent years and allows for cross-national comparability. The EU-SILC is a joint European effort to construct harmonized data for the EU member states. ${ }^{12}$ The EU-SILC dataset collects information on income, labor status, demographics, and living conditions at the national level, which is then processed and provided to researchers as a harmonised User Database (UDB). The Spanish sample size is 72,247 cases (37,491 in 2005 and 34,756 in 2011) and the Italian sample size is 103,946 cases (56,105 in 2005 and 47,841 in 2011).

We used the 2005 and 2011 waves of the EU-SILC, which include an intergenerational module containing information on attributes related to the family of origin - useful information given the intergenerational transmission of single motherhood (Dronkers and Härkönen 2008; Musick and Mare 2006). In addition, these two waves offer information from periods before and after the economic crisis. It is important to

\footnotetext{
${ }^{10}$ http://www.ggp-i.org/data/harmhistories.html

${ }^{11}$ Spain is included in the Harmonized Histories. However, these data were collected in 2006 and therefore there is no information on the characteristics of single-mother families during the economic crisis. Furthermore, the 2005 and 2011 waves of the EU-SILC include an inter-generational module containing information on attributes related to the family of origin. The Harmonized Histories only has information on parental divorce, while the 2005 and 2011 waves of the EU-SILC include information on the structure of the mother's family of origin and grandmother's labor status and educational level.

${ }^{12} \mathrm{http} / / / \mathrm{ec}$. europa.eu/eurostat/web/microdata/european_union_statistics_on_income_and_living_conditions
} 
note that we have not included waves between 2005 and 2011 in order to increase the sample size, since by "using pooled data from the EU-SILC cross-sectional files, some individuals and/or households will be present in the data for only one year, while for others there will be repeated observations" and "there is no means of determining which observations are repeated and which are not” (Iacovou, Kaminska, and Levy 2012).

We restricted our sample to mothers aged 25 to 59 with children younger than 18 . Our working sample is 10,815 mothers for Italy and 7,926 for Spain. Missing cases related to mothers' characteristics account for $2 \%$ of the original sample in Spain and $0.1 \%$ in Italy. Missing cases related to intergenerational information account for $4 \%$ of the sample, but we have created a dummy variable for these cases in order to minimize the amount of sample lost. Thus, our working sample is 10,802 for Italy and 7,798 for Spain.

\subsection{Variables}

\subsubsection{Outcome variable: Family structure}

In order to create our family structure variable, we followed Chzhen and Bradshaw's procedure (Chzhen and Bradshaw 2012) using the household-type variable, and we also identified whether the adults living with the children are their father ${ }^{13}$, mother, or another relative. Hence, our family structure variable has two categories: 1) single mother, referring to mothers who live without a partner, regardless of whether they live alone or with another adult who is not their partner, such as living with the mother's parents; and 2) mother in a two-parent family, referring to mothers who live with the children's father or stepfather, with or without other adults. We have found that in Italy

\footnotetext{
${ }^{13}$ The EU-SILC database does not distinguish whether a mother's partner is the natural father or a stepparent. For this reason we include mothers in stepparent and two-parent families in the same category in our analysis. We have been unable to find any previous research focused on educational differences between stepparent families and two-parent biological families that could help us to evaluate the relationship. However, we know that women's repartnering in Europe has a non-significant or negative association with education (Sweeney 2010). Several studies show that the proportion of children that live in stepmother families is greater in Spain than in Italy (e.g., Bjarnason and Arnarsson 2011). In addition, no significant association between repartnering and educational level has been found in Italy (Meggiolaro and Ongaro 2008), while mothers with lower educational levels are more likely to repartner in Spain (Treviño and Gumà 2013). Therefore, we believe that the main findings of our study, such as the fact that there are major differences in the relationship between mother's education and the probability of being single mothers between countries, are not overestimated. On the contrary, they might even be underestimated in our models. For this reason, we think that the magnitude of the difference of the effect of mother's education would be greater if we could compare single mothers to mothers in two-parent biological families, instead of comparing mothers in two-parent families which include both stepparent and two-parent biological families.
} 
around $30 \%$ of single mothers live with another adult who is not their partner, in most cases the mother's parents, while in Spain this percentage increases to $46 \%$.

Table 1 shows the descriptive figures on percentages and means by country of the dependent and independent variables used in the analyses. In Spain, the number of single mothers and mothers in two-parent families is 841 (9\%) and 6,967 (91\%), respectively, while in Italy the number of single mothers is 1,217 (10\%) and the number of mothers in two-parent families is 9,585 (90\%).

Table 1: Descriptives of percentages and means by country

\begin{tabular}{|c|c|c|}
\hline & Spain & Italy \\
\hline \multicolumn{3}{|l|}{ Mother's family structure } \\
\hline Two-parent family & $91(6,967)$ & $90(9,585)$ \\
\hline Single-mother family & $9(841)$ & $10(1,217)$ \\
\hline \multicolumn{3}{|l|}{ Mother's education } \\
\hline Lower secondary education or less & 43 & 41 \\
\hline Upper secondary education & 25 & 44 \\
\hline Tertiary education & 32 & 15 \\
\hline \multicolumn{3}{|l|}{ Type of residential area } \\
\hline Densely populated area & 50 & 44 \\
\hline Intermediate area & 23 & 40 \\
\hline Thinly populated area & 27 & 16 \\
\hline \multicolumn{3}{|l|}{ Mother's birth country } \\
\hline Country of residence & 89 & 87 \\
\hline European country & 3 & 3 \\
\hline Non-European country & 8 & 10 \\
\hline \multicolumn{3}{|l|}{ Mother's marital status } \\
\hline Married at some point & 93 & 94 \\
\hline Never married & 7 & 6 \\
\hline Number of children & $\mathrm{M}=1.54$ & $\mathrm{M}=1.53$ \\
\hline \multicolumn{3}{|l|}{ Mother's age } \\
\hline 40 years old or younger & 52 & 51 \\
\hline Older than 40 years old & 48 & 49 \\
\hline \multicolumn{3}{|l|}{ Year of the survey } \\
\hline Year 2005 & 47 & 49 \\
\hline Year 2011 & 53 & 51 \\
\hline \multicolumn{3}{|c|}{ Structure of mother's family of origin at age 14} \\
\hline Lived with both natural parents & 91 & 93 \\
\hline Lived with only the mother or father & 6 & 6 \\
\hline Lived without parents & 3 & 1 \\
\hline
\end{tabular}


Garriga, Sarasa \& Berta: Mother’s educational level and single motherhood

Table 1: (Continued)

\begin{tabular}{|c|c|c|}
\hline & Spain & Italy \\
\hline \multicolumn{3}{|l|}{ Grandmother's education } \\
\hline Lower secondary education or less & 93 & 87 \\
\hline Upper secondary education or more & 7 & 13 \\
\hline \multicolumn{3}{|l|}{ Grandmother's labor status } \\
\hline Employed grandmother & 70 & 71 \\
\hline Unemployed grandmother & 30 & 29 \\
\hline \multicolumn{3}{|l|}{ Spanish regions } \\
\hline Canary Islands & $5(446)$ & \\
\hline Asturias & $2(257)$ & \\
\hline Ceuta and Melilla & $1(157)$ & \\
\hline Catalonia & $16(809)$ & \\
\hline Cantabria & $1(217)$ & \\
\hline Extremadura & $2(285)$ & \\
\hline Balearic Islands & $1(285)$ & \\
\hline Murcia & $4(403)$ & \\
\hline Galicia & $5(453)$ & \\
\hline Madrid & $13(604)$ & \\
\hline Navarra & $4(371)$ & \\
\hline La Rioja & $1(258)$ & \\
\hline Andalusia & $20(1,064)$ & \\
\hline Valencia & $11(666)$ & \\
\hline Castile and La Mancha & $5(453)$ & \\
\hline Basque Country & $1(249)$ & \\
\hline Castile and León & $5(436)$ & \\
\hline Aragón & $3(341)$ & \\
\hline \multicolumn{3}{|l|}{ Italian regions } \\
\hline Northeast & & $18(2,507)$ \\
\hline Center & & $19(2,517)$ \\
\hline Northwest & & $26(2,415)$ \\
\hline South & & $25(2,422)$ \\
\hline Islands & & 12 (949) \\
\hline $\mathrm{N}$ & 7,798 & 10,802 \\
\hline
\end{tabular}

\subsubsection{Independent variables}

The mother's educational level is the main independent variable, which is measured using the highest ISCED level successfully completed. The educational levels, grouped according to the International Standard Classification of Education (ISCED 1997), are: 
low secondary education or less (ISCED 1 and 2); upper secondary education (ISCED 3 and 4), which includes upper secondary education and post-secondary non-tertiary education; and tertiary education (ISCED 5 and 6), which includes first- and secondstage tertiary education.

The other predictor variables have been coded as follows: type of residential area measures the degree of urbanization of the area where the mother lives, distinguishing between densely populated, intermediate, and thinly populated. Country of birth is defined as born in the respondent's country of residence (Italy or Spain), born in another European country, and born outside of Europe. We have estimated a quadratic function of single motherhood depending on age, and the results show an inverted U-form function with its changing slope sign at around 40-years-old; hence, mother's age has two categories: under-40 and over-40. Mother's marital status indicates whether she has ever been married. Mothers who have been married include widowed, divorced, and married mothers. We have not included all categories of the mother's marital status because there is a high multicollinearity between the category of divorced or separated mothers and single motherhood. In any case, the percentages of the different types of marital status are very similar in both countries. Other control variables are the year of the interview and the number of children living at home.

As shown in Table 1, we also include regions of residence. The Spanish regions are the Autonomous Communities (NUTS 2), but the Italian regions are grouped into Northwest, Northeast, Center, and South and Islands, because the EU-SILC database only gives information for Italian regions at the NUTS 1 level. Out-of-wedlock births are more frequent in those regions where traditional norms are weaker, either due to the practices of tourists from Northern Europe being copied, as in the Balearic and Canary Islands, or because the regions are highly urbanized, with large cities that allow for more freedom of choice, as in Catalonia and Madrid (López-Menchero 2003). The distribution of divorce rates among the Spanish regions follows a similar pattern as outof-wedlock births (Spanish Institute of Statistics 2013b). Furthermore, women's activity rate is the highest in these four regions, although the islands are among the regions with the lowest share of women with college degrees. Generally speaking, the regions of southern Spain (Andalusia, Extremadura, Castilla-La Mancha, and Murcia) are more dependent on agricultural production, but there is not as clear a cleavage as in Italy. Some central (Castilla-Leon) and northern (Asturias, Galicia, and Rioja) regions of Spain also depend on agriculture more than the average. In the specification of our model, we selected Catalonia in Spain and north-west Italy as reference categories to compare with the other regions, because these regions are historically among the most modernized in each country.

The structure of the mother's family of origin when she was 14 has three categories: lived with both parents, lived with only the mother or the father, and lived 
without parents. In our model, the educational level of the grandmother when the mother was 14 distinguishes between two categories: lower secondary education or less and upper secondary education or more. We only include two categories because few grandmothers have an educational level higher than lower secondary education or less. The labor status of the grandmother when the mother was 14 identifies whether the mother in the family of origin was employed. Information about the father is not included since most mothers who lived only with their mother at age 14 did not answer the questions about their father in the intergenerational module.

\section{Results}

\subsection{What are the main characteristics of Spanish and Italian single mothers compared to mothers in two-parent families?}

As mentioned, previous studies (Flaquer, Almeda, and Navarro 2006; Garriga 2010) show a positive relationship between educational level and single motherhood in both countries, using data from the 1990s or early 2000s. However, using more recent data (EU-SILC 2005, 2011), Table 2 shows that in Spain, the proportion of single mothers is higher among those with tertiary education than among those with lower secondary education or less, while the opposite is true in Italy. In fact, the proportion of women with tertiary education who are single mothers is twice as large in Italy as in Spain.

Table 2: Differences in percentages and means by family structure and country.

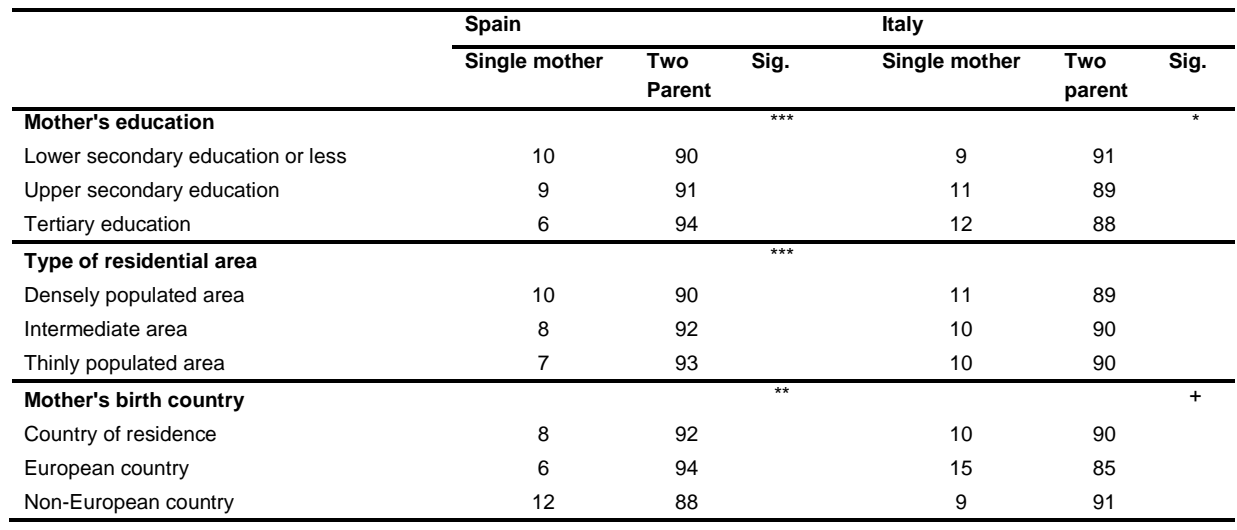


Table 2: (Continued)

\begin{tabular}{|c|c|c|c|c|c|c|}
\hline & \multicolumn{3}{|l|}{ Spain } & \multicolumn{3}{|l|}{ Italy } \\
\hline & Single mother & $\begin{array}{l}\text { Two } \\
\text { Parent }\end{array}$ & Sig. & Single mother & $\begin{array}{l}\text { Two } \\
\text { parent }\end{array}$ & Sig. \\
\hline Mother's marital status & & & 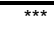 & & & \\
\hline Married at some point & 7 & 93 & & 9 & 91 & 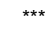 \\
\hline Never married & 30 & 70 & & 40 & 60 & 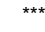 \\
\hline Number of children & $M=1.36$ & $M=1.56$ & 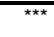 & $\mathrm{M}=1.34$ & $M=1.55$ & $\overline{\star \star \star \star ~}$ \\
\hline Mother's age & & & * & & & $\overline{* \star \star}$ \\
\hline 40 years old or younger & 10 & 90 & & 12 & 88 & \\
\hline Older than 40 years & 8 & 92 & & 9 & 91 & \\
\hline Year of the survey & & & & & & 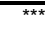 \\
\hline Year 2005 & 9 & 91 & & 9 & 91 & \\
\hline Year 2011 & 9 & 91 & & 12 & 88 & \\
\hline $\begin{array}{l}\text { Structure of mother's family of oric } \\
\text { age } 14\end{array}$ & & & ** & & & ** \\
\hline Lived with both natural parents & 8 & 92 & & 10 & 90 & \\
\hline Lived with only the mother or father & 12 & 88 & & 15 & 85 & \\
\hline Lived without parents & 10 & 90 & & 10 & 90 & \\
\hline Grandmother's education & & & * & & & * \\
\hline Upper secondary education or more & 9 & 91 & & 12 & 88 & \\
\hline Lower secondary education or less & 11 & 89 & & 10 & 90 & \\
\hline Grandmother's labor status & & & * & & & * \\
\hline Employed grandmother & 8 & 92 & & 12 & 88 & \\
\hline Unemployed grandmother & 10 & 90 & & 10 & 90 & \\
\hline
\end{tabular}

Note: Significances estimated by Chi square and T-test. $+p<0.10{ }^{\star} p<0.05 *{ }^{*} p<0.01 * \star *<0.001$.

Nevertheless, Table 2 also shows that the proportion of single mothers varies depending on other predictors of single motherhood, and that these differences diverge by country. In Spain, mothers living in urban areas are more likely to be single than those living in rural areas, while few differences are found in Italy. The proportion of single mothers is greater among women born in non-European countries than among mothers born in Spain, while the opposite is true in Italy. In Spain, the proportion of single mothers is greater among women born in Spain than among those born in European countries. In contrast, the proprotion of single mothers is lower among women born in Italy than among those born in other European countries. Comparing indicators before and after the economic crisis, no growth in single motherhood was found in Spain, but there was a 30\% increase in single-mother families in Italy between 2005 (9\%) and 2011 (12\%). The higher ratio of single motherhood in Italy was also found by Iacovou and Skew in the EU-SILC 2007 (Iacovou and Skew 2010), before the crisis. The evolution of single motherhood rates in Spain is consistent with the increased costs of single motherhood under economic recession cycles: since the 
economic crisis has been deeper in Spain, the diffusion effects may be more restrained in this country.

Notwithstanding, both countries also have important similarities. The greater the number of children, the greater the likelihood of being a two-parent family. The proportion of single-mother families is higher among never-married women in both countries. This last finding is in accordance with previous research that shows that cohabiting couples have a higher chance of dissolution (Kiernan 2004). However, considering that a previous study indicated that the number of cohabiting women with children is higher in Spain than in Italy (Creighton et al. 2013), it is surprising that in our data the percentage of never-married single mothers is greater in Italy than in Spain. Considering the mother's family of origin, there are fewer single mothers among mothers that lived with their natural parents at age 14 than among those that lived in other family types. There are also significant differences in the proportion of single mothers depending on the grandmother's education and labor status. The likelihood of being a single mother is greater among women whose mother was employed when the woman was 14 years old, and single motherhood is also more likely among mothers whose mothers have upper secondary education or more. The magnitude of these differences is similar between countries.

Finally, the likelihood of being a single mother differs by region in both countries, but it is difficult to find a single explanation in the Spanish case, while in Italy the cleavage between the north and the south is clear (see Table 3). However, with these descriptives we cannot rule out that the observed difference between countries in the percentage of single mothers by mother's educational level is explained by differences in other characteristics of the mother and the context. Hence, logistic regressions were performed to test the effect of the mother's educational level while controlling for other independent variables. The statistical methodological approach based on logistic regression is justified by the choice of the dependent variable built as a binary variable.

Table 3: $\quad$ Percentages of family structures by Spanish and Italian regions.

\begin{tabular}{lccc}
\hline & Single mothers & Two-parent & Significance \\
\hline Spanish regions (NUTS II) & 14 & 86 & \\
Canary Islands & 12 & 88 & \\
Asturias & 11 & 89 & \\
Ceuta and Melilla & 10 & 90 \\
Catalonia & 10 & 90 \\
Cantabria & 10 & 90 \\
Extremadura & 10 & 90 \\
Balearic Islands & 10 & 90
\end{tabular}


91

Table 3: (Continued)

\begin{tabular}{lccc}
\hline & Single mothers & Two-parent & Significance \\
\hline Madrid & 9 & 91 & \\
Navarra & 8 & 92 & \\
La Rioja & 8 & 92 & \\
Andalusia & 8 & 92 & \\
Valencia & 8 & 92 & \\
Castile and La Mancha & 6 & 94 & \\
Basque Country & 5 & 95 \\
Castile and León & 5 & 95 & \\
Aragón & 4 & 96 & \\
Italian regions (NUTS III) & & & \\
Northeast & 12 & 88 & \\
Center & 12 & 88 & \\
Northwest & 11 & 89 & \\
South & 9 & 91 & \\
Islands & 7 & 93 & \\
\hline
\end{tabular}

Note: $+p<0.10 * p<0.05 * x<0.01<0.001$

\subsection{Does the effect of mother's educational level on single motherhood differ between Spain and Italy?}

Using logistic regressions, we tested the interactions between country and education as well as between country and the key variables, such as type of residential area, country of birth, and year of the survey. Models with interaction terms had improved fit over models with only main effects, so we present models separately for Spain and Italy. ${ }^{14}$ Two logistic models were estimated (see results in Table 4). In the first model (Model 1) we estimated two separated bivariate models by country, not including the covariates. In the second model (Model 2) we also estimated two separate multivariate models, but including the covariates presented in Table 1 . In Model 1, a negative educational gradient of single motherhood is observable in Spain and it increases when control variables are introduced in Model 2. This increase is mainly due to the inclusion of grandmother's education, confirming our prediction that a change in the sign between generations would bias the estimates of the effect of education among

\footnotetext{
${ }^{14}$ Estimates are not shown but are available upon request.
} 
daughters. The addition of the other control variables does not change the coefficient. ${ }^{15}$ As hypothesized, mothers with lower educational levels are relatively more likely to be single mothers than mothers with higher educational levels, the highest difference being between mothers with tertiary education and the others.

Table 4: Logistic regressions of the relative likelihood of single motherhood versus two-parent family for Spain, Italy, and both countries together

\begin{tabular}{|c|c|c|c|c|}
\hline & \multicolumn{2}{|c|}{ Spain } & \multicolumn{2}{|c|}{ Italy } \\
\hline & $\begin{array}{c}\text { Model } 1 \\
\text { Coeff. }\end{array}$ & $\begin{array}{c}\text { Model } 2 \\
\text { Coeff. }\end{array}$ & $\begin{array}{c}\text { Model } 1 \\
\text { Coeff. }\end{array}$ & $\begin{array}{c}\text { Model } 2 \\
\text { Coeff. }\end{array}$ \\
\hline \multicolumn{5}{|l|}{ Mother's education } \\
\hline Lower secondary education or less & Ref & Ref & Ref & Ref \\
\hline Upper secondary education & -0.13 & $-0.21+$ & $0.18^{*}$ & 0.10 \\
\hline Tertiary education & $-0.52^{\star \star \star}$ & $-0.62^{\star \star \star}$ & $0.26^{\star}$ & 0.13 \\
\hline \multicolumn{5}{|l|}{ Country (Spain as reference) } \\
\hline \multicolumn{5}{|l|}{ Mother's education* country } \\
\hline \multicolumn{5}{|l|}{ Lower secondary education or less ${ }^{*}$ country } \\
\hline \multicolumn{5}{|l|}{ Upper secondary education ${ }^{\star}$ country } \\
\hline \multicolumn{5}{|l|}{ Tertiary education* country } \\
\hline \multicolumn{5}{|l|}{ Type of residential area } \\
\hline Densely populated area & & Ref & & Ref \\
\hline Intermediate area & & $-0.30^{*}$ & & -0.11 \\
\hline Thinly populated area & & $-0.38^{\star \star}$ & & -0.05 \\
\hline \multicolumn{5}{|l|}{ Mothers' birth country } \\
\hline Country of residence & & Ref & & Ref \\
\hline European country & & -0.44 & & 0.15 \\
\hline Non-European country & & $0.29+$ & & -0.26 \\
\hline Mother's marital status: never married & & $1.68^{\star \star \star}$ & & $1.91^{\star \star \star}$ \\
\hline Number of children at home & & $-0.45^{\star \star \star}$ & & $-0.47^{\star \star \star}$ \\
\hline Mother's age: younger than 40 & & $-0.38^{\star \star \star}$ & & $-0.45^{\star \star \star}$ \\
\hline Year of the survey: 2011 & & -0.03 & & $0.21^{\star \star}$ \\
\hline \multicolumn{5}{|l|}{ Structure of mother's family of origin at age 14} \\
\hline Lived with both natural parents & & Ref & & Ref \\
\hline Lived only with the mother or father & & 0.12 & & $0.35^{\star}$ \\
\hline Lived without parents & & -0.01 & & 0.04 \\
\hline Grandmother's education: upper secondary education or more & & $0.52^{\star \star}$ & & 0.05 \\
\hline Grandmother's labor status: employed grandmother & & 0.07 & & 0.01 \\
\hline
\end{tabular}




\section{Table 4: (Continued)}

\begin{tabular}{|c|c|c|c|c|}
\hline & \multicolumn{2}{|c|}{ Spain } & \multicolumn{2}{|c|}{ Italy } \\
\hline & $\begin{array}{c}\text { Model } 1 \\
\text { Coeff. }\end{array}$ & $\begin{array}{c}\text { Model } 2 \\
\text { Coeff. }\end{array}$ & $\begin{array}{c}\text { Model } 1 \\
\text { Coeff. }\end{array}$ & $\begin{array}{c}\text { Model } 2 \\
\text { Coeff. }\end{array}$ \\
\hline Catalonia & & Ref & & \\
\hline Canary Islands & & $0.13+$ & & \\
\hline Asturias & & 0.15 & & \\
\hline Ceuta and Melilla & & 0.26 & & \\
\hline Cantabria & & -0.15 & & \\
\hline Extremadura & & 0.28 & & \\
\hline Balearic Islands & & -0.15 & & \\
\hline Murcia & & 0.24 & & \\
\hline Galicia & & -0.06 & & \\
\hline Madrid & & -0.26 & & \\
\hline Navarra & & -0.19 & & \\
\hline La Rioja & & -0.28 & & \\
\hline Andalusia & & -0.19 & & \\
\hline Valencia & & -0.24 & & \\
\hline Castile and La Mancha & & -0.33 & & \\
\hline Basque Country & & $-0.83^{\star \star}$ & & \\
\hline Castile and León & & $-0.48+$ & & \\
\hline Aragón & & $-1.03^{\star \star}$ & & \\
\hline \multicolumn{5}{|l|}{ Italian regions } \\
\hline Northwest & & & & Ref \\
\hline Northeast & & & & $0.21+$ \\
\hline Center & & & & 0.19 \\
\hline South & & & & 0.08 \\
\hline Islands & & & & $-0.33+$ \\
\hline $\mathrm{BIC}$ & $5504 e+06$ & $5067 e+06$ & $8232 e+06$ & $7513 e+06$ \\
\hline Constant & $-2.17^{\star \star \star}$ & $-0.75^{\star \star}$ & $-2.27^{\star \star \star}$ & $-1.64^{\star \star \star}$ \\
\hline Pseudo r2 & 0.01 & 0.08 & 0.00 & 0.09 \\
\hline $\mathrm{N}$ & 7,798 & 7,798 & 10,802 & 10,802 \\
\hline
\end{tabular}

Note: Missing dummy variables of mother's family of origin structure and socioeconomic characteristics of the grandmother are not shown. $+p<0.10{ }^{\star} p<0.05{ }^{\star \star} p<0.01<0.001$. 
What is the relationship between mother's educational level and family structure in Italy, compared to Spain? First, the bivariate analysis in Model 1 shows that in Italy there is a positive educational gradient for single motherhood. Compared with Spain, Italian higher-educated mothers have a greater chance of being single mothers. However, the educational gradient disappears when control variables are considered (Model 2). Grandmother's education, region, and marital status are the variables that mainly explain the disappearance of the educational effect. ${ }^{16}$

Also as predicted, the effect of the year of survey and country of birth diverge by country. Model 2 indicates that in Italy, single motherhood was more common in 2011 than in 2005, while no change is observed in Spain. Since the crisis has been deeper in Spain than in Italy, these results are consistent with the hypothesis that economic crises restrain single motherhood. Mothers born in a non-European country are more likely to be single mothers than Spanish mothers, while country of birth is not associated with single motherhood in Italy. These results are in accordance with the results found by other researchers that show how immigrants from Latin America are more common in Spain than in Italy and that the frequency of single-mother families is greater among immigrants from this region than among immigrants from other regions (Domingo and Parnau 2006; Muñoz de Bustillo and Anton 2010; INE, Padrón Municipal de Habitantes 2011; Istat 2013). Finally, although it was hypothesized that mothers who live in densely populated areas would have higher chances of being single mothers than those from other areas, Model 2 shows that this association is observed in Spain but not in Italy.

The effects of the other predictors of single motherhood go in the expected direction and are similar in both countries. Model 2 shows that mothers who have never been married, as well as those older than 40 , have higher chances of being single mothers. It also shows that the number of children at home is negatively associated with the probability of being a single mother. No differences are observed between countries for individuals whose mother was working at age 14. In Spain, the educational level of the grandmother is positively associated with the probability of single motherhood. In Italy, mothers who lived in a single-parent family are more likely to also be single mothers. In both countries there are significant differences by region, but they are difficult to interpret without controlling for aggregate regional data related to economic and cultural factors. A multilevel model could help to solve this issue, but it is not the main purpose of our research.

${ }^{16}$ Estimates are not shown but are available upon request. 


\subsection{Does the main effect of educational level diverge by other characteristics of the mother?}

As mentioned in the analytical plan, in the second stage we aim to understand the relationship between educational level and mother's characteristics and context when predicting the likelihood of being a single mother. In each national sample we have estimated several interactions between mother's educational level and other characteristics, such as country of birth, marital status, and age, and between mother's educational level and contextual variables, such as type of residential area, year of the survey, and region. All interactions improve the BIC of the models. We compare the BIC values of the model with only main effects for each country (Model 2 in Table 4) and the models with interactions (shown in Appendix Tables A1, A2, and A3).

We present the results graphically to aid interpretation of the interaction. Figures 4 to 14 explain the results of the model, with the confidence intervals of the probability of being a single mother plotted on the graph. Each line corresponds to a level of the covariates, and each dot corresponds to a different educational level.

Considering the contextual variables, in Spain the negative gradient of education is greater for mothers living in urban areas than in thinly populated areas (Figure 4), whereas in Italy the gradient is positive, but some signals of change are observed in urban areas that are not densely populated (Figure 5). This change in Italy is also observable when the interaction with year is taken into consideration. The positive gradient in 2005 almost disappears in 2011 because of the increase in the likelihood of single motherhood among educated women with lower educational levels (Figure 7). In Spain, the interaction between mother's educational level and year of the survey shows minor differences, suggesting that the negative effect of educational level was already present in 2005 (Figure 6). 
Figure 4: Predicted probabilities for the interaction between type of residence area and education, Italy

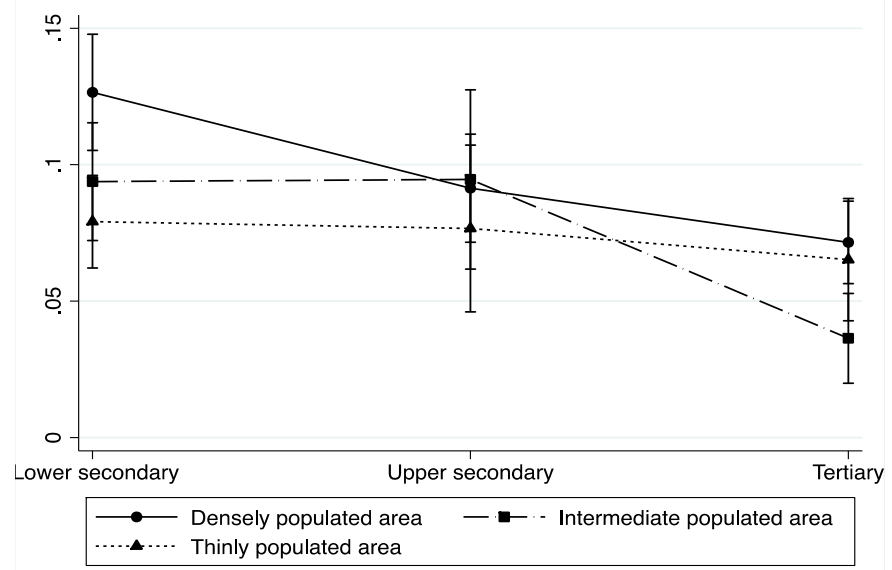

Note: This figure is based on Model 1 of Appendix Table $\mathrm{A} 1^{1 \prime}$.

Figure 5: Predicted probabilities for the interaction between type of residence area and education, Italy

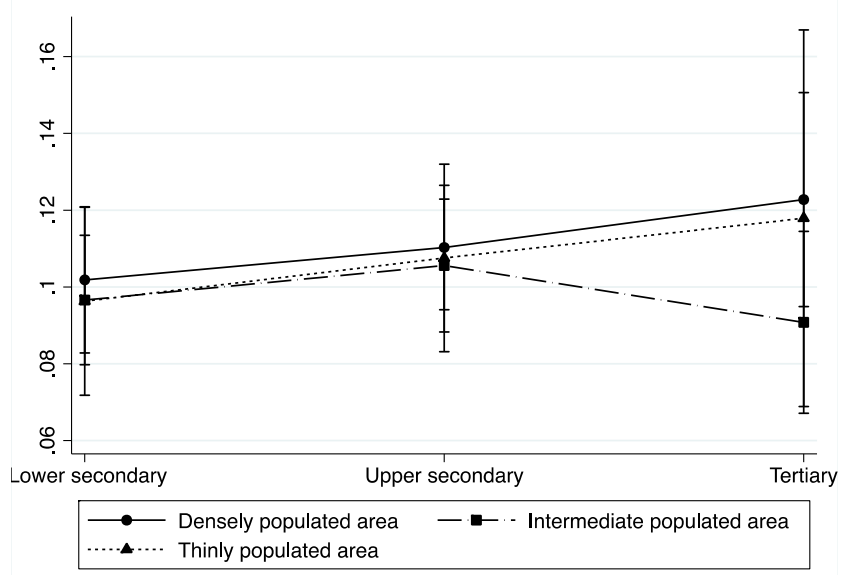

Note: This figure is based on Model 1 of Appendix Table A1.

${ }^{17}$ All figures on predicted probabilities are done using the Stata command margins at means (Greene 2012; Williams 2012). 
Figure 6: Predicted probabilities for the interaction between year of the survey and education, Spain

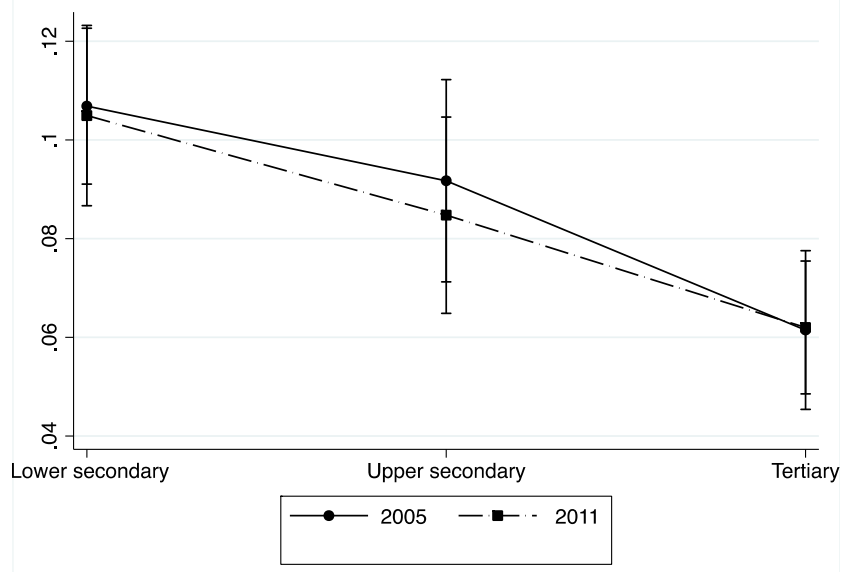

Note: This figure is based on Model 2 of Appendix Table A1.

Figure 7: Predicted probabilities for the interaction between year of the survey and education, Italy

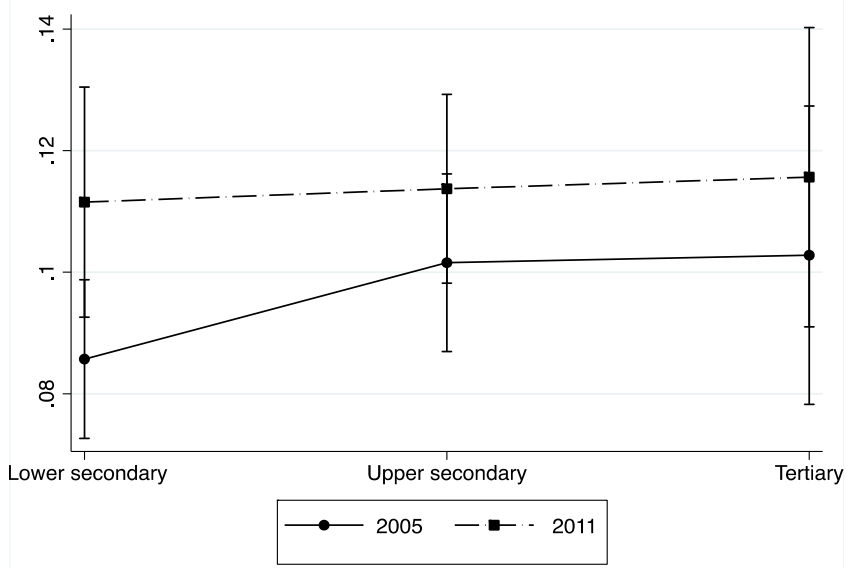

Note: This figure is based on Model 2 of Appendix Table A1. 
Interactions between the mother's educational level and Spanish regions have little substantive meaning. Estimates could be inefficient because the sample size is low in most regions (see Appendix Table A2). However, Figure 8 reveals that in northwest Italy the cumulative probability of being a single mother decreases as the mother's educational level increases, it is not substantially different in the northeast and center, and it rises with the mother's educational level in the south and especially in the islands.

Figure 8: Predicted probabilities for the interaction between mother's education and Italian regions

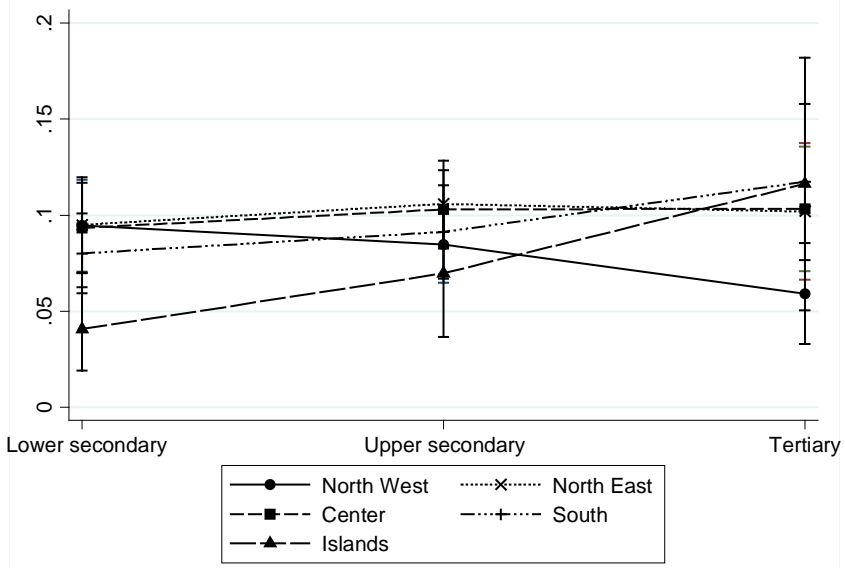

Note: This figure is based on Model 1 of Appendix Table A2.

Contrary to expectations, the effect of educational level on the probability of living in a single-mother family is the same for mothers who were born in Spain or Italy and for mothers who were born in other non-European countries (Figures 9 and 10). In Spain, mothers born in another European country show a more negative education gradient, but the small number of cases makes this estimate unreliable. The educational gradient diverges by marital status in both countries, but in opposite directions. In Spain, Figure 11 shows that the negative educational gradient in the likelihood of being a single mother is more pronounced among never-married mothers than among married mothers, whereas in Italy this trend is also pronounced, but in the opposite direction (Figure 12). 
Figure 9: Predicted probabilities for the interaction between mother's education and country of birth, Spain

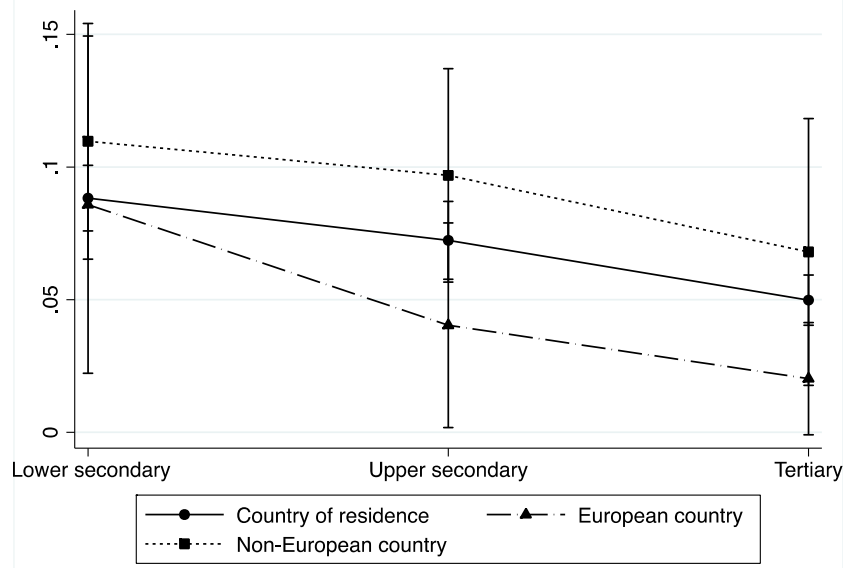

Note: This figure is based on Model 1 of Appendix Table A3.

Figure 10: Predicted probabilities for the interaction between mother's education and country of birth, Italy

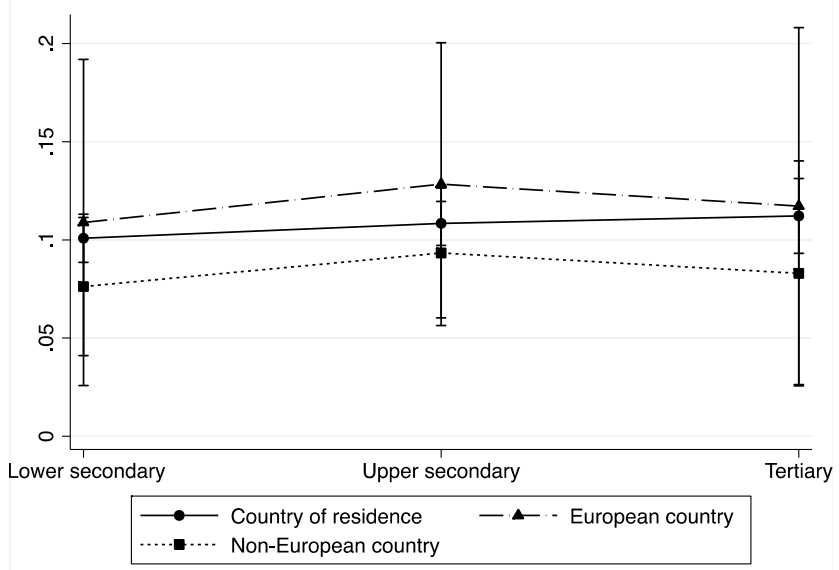

Note: This figure is based on Model 1 of Appendix Table A3. 


\section{Figure 11: Predicted probabilities for the interaction between mother's} education and mother's marital status, Spain ${ }^{18}$

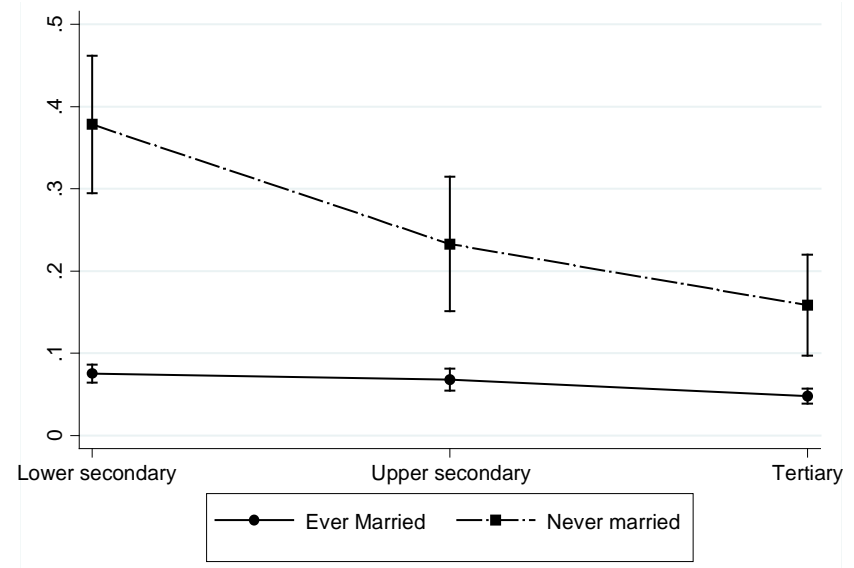

Note: This figure is based on Model 2 of Appendix Table A3.

Figure 12: Predicted probabilities for the interaction between mother's education and mother's marital status, Italy

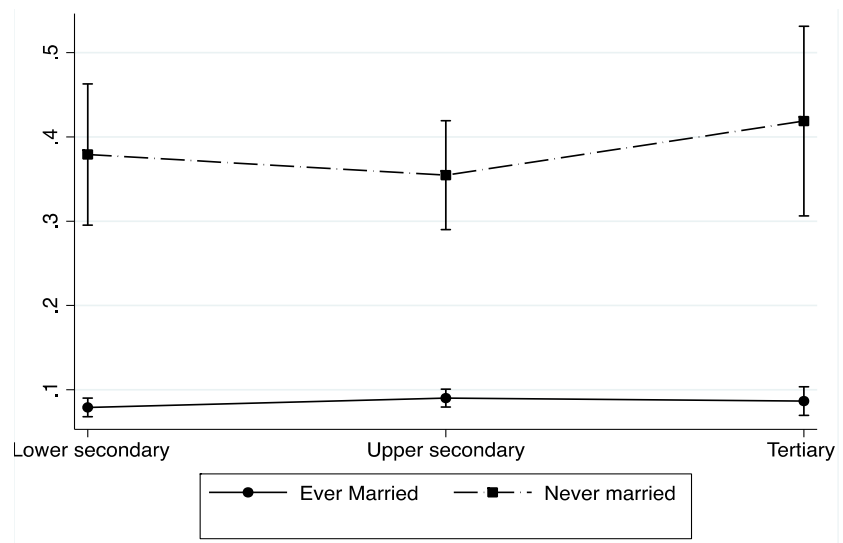

Note: This figure is based on Model 2 of Appendix Table A3.

${ }^{18}$ In Figures 11 and 12 the scale is different because the rate among never married is so high and is averaged out in the other estimates 
The relationship between education and the probability of being a single mother diverges by mother's age in both Spain and in Italy. Figure 13 shows that in Spain, for both old and young mothers, the cumulative predicted probability of being a single mother decreases as the mother's educational level increases. However, the negative effect of educational level is more pronounced among young mothers than old mothers. By contrast, Figure 14 shows that in Italy, when the educational level increases, the cumulative predicted probability of being a single mother declines for young mothers and rises for older ones. Comparing Spain and Italy, older women follow different patterns depending on the country. For young women from both countries, there is a drop in the cumulative predicted probability of being a single mother when the mother's educational level increases. However, this decline is stronger in Spain.

\section{Figure 13: Predicted probabilities for the interaction between mother's age and} education, Spain

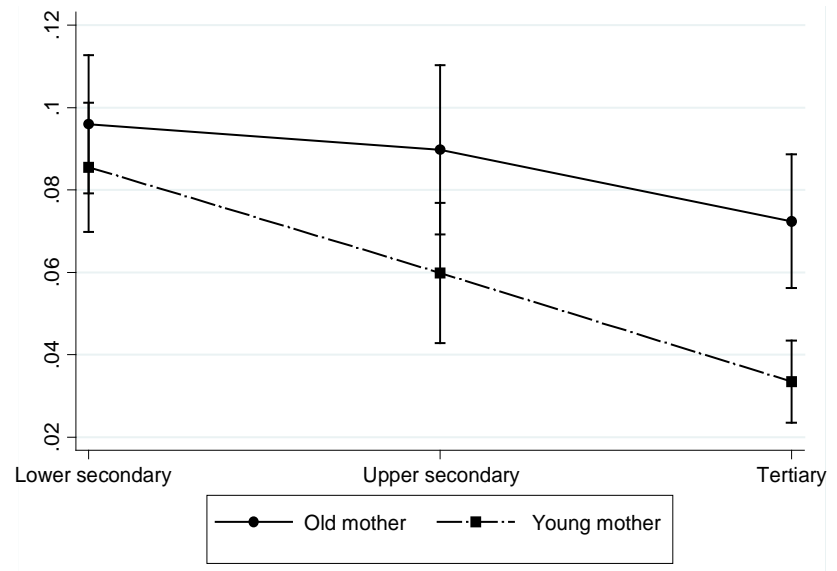

Note: This figure is based on Model 3 of Appendix Table A3. 
Figure 14: Predicted probabilities for the interaction between mother's age and education, Italy

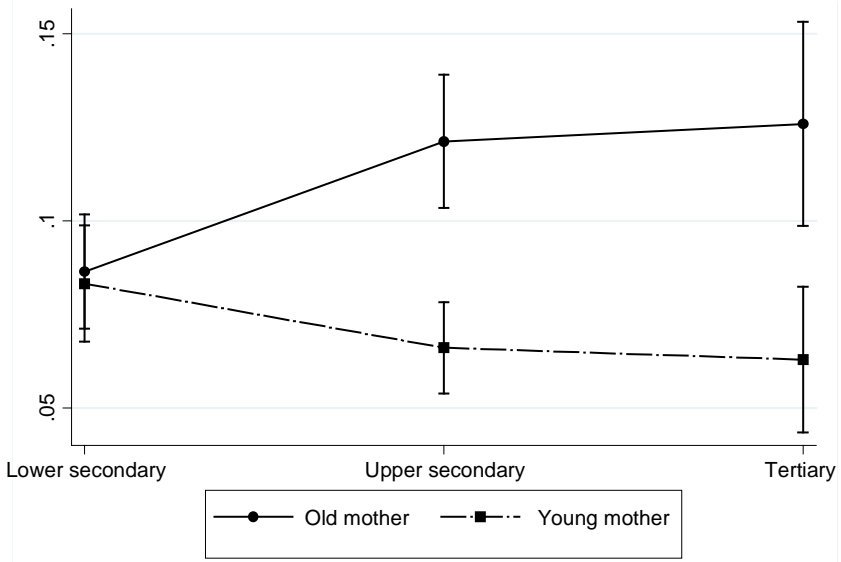

Note: This figure is based on Model 3 of Appendix Table A3.

\subsection{Robustness checks}

The main finding obtained in this paper indicates that in Spain the mother's educational level has a negative educational gradient, while in Italy there are no differences by education. We have tested the robustness of this finding with two alternative specifications. First, widowed single mothers have different socio-demographic characteristics than single mothers who are separated or divorced (Treviño 2006). However, we have found similar effects of mother's educational level by country when both including and excluding widows in the sample. Finally, another robustness check excluded mothers born in a non-European country from our main sample. As mentioned, mothers from Latin America have higher chances of becoming single mothers than mothers from other countries of origin, and Latin American mothers are more common in Spain. Therefore, differences between countries in the relationship between the mother's educational level and family structure may be due to the differences in the mothers' home countries (Domimgo and Parnau 2006; Muñoz de Bustillo and Anton 2010; INE, Padrón Municipal de Habitantes 2011; Istat 2013). Our data do not provide information on the country of origin, but if we exclude mothers 
born in non-European countries from the sample the substantial findings do not change. ${ }^{19}$

\section{Discussion}

Previous research performed using data from the 1990s or early 2000s showed that single mothers had higher educational levels than mothers in two-parent families in both Spain and Italy (Flaquer, Almeda, and Navarro 2006; Garriga 2010; McLanahan 2004). The most recent literature on divorce in Southern Europe has found no clear negative gradient of educational level (Bernardi and Martínez-Pastor 2011; Gabrielli and Vignoli 2013). However, those studies have utilized samples that represent all married women, while we have restricted the sample to mothers with children younger than 18. Furthermore, we have added intergenerational variables to our model. Among them, the grandmother's educational level has been proven to be especially important in getting unbiased estimates of the effect of the mother's educational level on the relative odds of single motherhood. Taking it into account made the positive effect of educational level in Italy statistically non-significant and increased the effect of mother's educational level in Spain. It shows how important it is to control for grandmother's educational level when a change in the sign of education effect occurs between generations, because then the estimates of the education effect among daughters are biased.

Our estimates reveal that the covariation between educational level and single motherhood has become negative in Spain. That sign is even stronger for younger mothers, indicating that the new trend is going to rise in the future. Furthermore, it is also stronger among urban and never-married mothers, both of which are increasing in Spain. We can establish that this negative relationship was not triggered by the economic crisis since it already existed in 2005 before the economic downturn, as well as in 2011 after its onset.

Is Italy following the same pattern as Spain? The effect of the mother's educational level on the relative likelihood of being a single mother is not significant in Italy, but we had expected to find a positive covariation between single motherhood and educational level, as was found some years ago (Garriga 2010). This finding, the lack of educational difference by family type in Italy, may suggest that the change in the educational gradient of the probability of single motherhood is also underway in this country but it is not yet completed. In support of this hypothesis, we have seen that the

\footnotetext{
${ }^{19}$ Tables not shown, available upon request.
} 
positive gradient of education in 2005 had disappeared by 2011. Furthermore, younger Italian mothers with low educational levels now have higher chances of being single mothers than those with higher educational levels. Additionally, northwest Italy is following the same pattern as Spain, while the positive gradient of education only exists in the more backward regions. Hence, although the negative effect of educational level is stronger among younger Spanish mothers than among their Italian counterparts, it seems that Italy is heading with Spain towards a U-turn in the association between educational level and single motherhood.

This social transformation in Southern Europe cannot be considered without recognizing the potential negative consequences for future generations. Single-mother households that are dealing with the economic crisis that started in 2008 have lower socioeconomic backgrounds than single mothers who suffered through previous crises, and therefore the consequences of this crisis for children in single-parent families might be even more negative, especially in Spain. McLanahan (2004) warned that under the Second Demographic Transition, children born to the least-educated women are losing resources in terms of money and time with their parents, while those born into the most educated families are gaining resources. The main explanation for this increase in the disparities of children's resources is the concentration of single motherhood among less-educated women. In other words, less-educated women, who already have the fewest opportunities and resources, are those who separate more frequently (McLanahan 2004). One of the potential consequences of this demographic shift is the increasing inequality among mothers and children from different socio-economic backgrounds and family types in terms of well-being and life chances (McLanahan and Perscheki 2008; Härkönen 2014). Future research should explore whether the reversal in the relationship between educational level and single motherhood has effectively increased children's inequalities.

\section{Acknowledgements}

This research has been possible thanks to the grants provided by the European Research Council (Grant \#269387), the Spanish Ministry of Economy and Competitiveness (Grants CSO2013-43461-R and CSO2012-33476) and the Catalan Research Program RECERCAIXA 2012(Grant \# PRO8113) as well as the financial support to Anna Garriga from the Juan de la Cierva Postdoctoral Program of Ministry of Economy and Competitiveness (Government of Spain). A previous version of this article was presented at the Family Polarization Workshop, Barcelona, University Pompeu Fabra, March $28^{\text {th }}$, 2014. This workshop was organized by a project financed by an ERC (European Research Council) Advanced Grant on Family Polarization and 
Demographic Change directed by Gøsta Esping-Andersen. The authors have benefited from valuable comments on earlier drafts by Juho Härkönen, Fabrizio Bernardi, Gøsta Esping-Andersen, and Arnstein Aassve. We thank the Associate Editor and two anonymous reviewers for their constructive comments, which helped us to improve the manuscript. 


\section{References}

Becerril, D. (2008). La percepción social del divorcio en España. Revista Española de Investigaciones Sociológicas 123(1): 187-208.

Bernardi, F. and Martinez-Pastor, J.I. (2011). Female education and marriage dissolution: Is it a selection effect? European Sociological Review 27(6): 693707. doi:10.1093/esr/jcq031.

Bjarnason, T. and Arnarsson A.M. (2011). Joint physical custody and communication with parents: A cross-national study of children in 36 western countries. Journal of Comparative Family Studies 642(6): 871-890.

Blossfeld, H.P., de Rose, A., Hoem, J., and Rohwer, G. (1995). Education, modernization, and the risk of marriage disruption in Sweden, West Germany, and Italy. In: Oppenheim, K. and Jensen, A.-M. (eds.). Gender and Family Change in Industrialized Societies. Oxford: Clarendon Press: 200-222.

Breen, R. and Jonsson, J.O. (2005). Inequality of opportunity in comparative perspective: Recent research on educational attainment and social mobility. Annual Review of Sociology 31: 223-243. doi:10.1146/annurev.soc. 31.041304.122232.

Chan, T.C. and Halpin, B. (2008). The instability of divorce risk factors in the UK. [Unpublished manuscript]. Oxford: University of Oxford. http://users.ox.ac.uk/ $\sim$ sfos0006/papers/change8.pdf.

Chzhen, Y. and Bradshaw, J. (2012). Lone parents, poverty and policy in the European Union. Journal of European Social Policy 22(5): 487-506. doi: 10.1177/0958928712456578.

Creighton, M., Esping-Andersen, G., Rutigliano., R., and Van Damme, V. (2013). ¿Influye la inestabilidad de la pareja en la fecundidad? In: Esping-Andersen, G. (ed.). El déficit de natalidad en Europa. La singularidad del caso Español. Barcelona: Obra Social La Caixa: 112-133.

De Graaf, P.M. and Kalmijn, M. (2003). Alternatives routes in the remarriage market: Competing-risk analyses of union formation after divorce. Social Forces 81(4): 1459-1498. doi:10.1353/sof.2003.0052.

Domingo, A. and Parnau, M. (2006). Familia y estructura del hogar de la población de nacionalidad extranjera, 2001. Barcelona: Centre d’ Estudis Demogràfics. 
Dominguez-Folgueras, M. (2013). Is cohabitation more egalitarian? The division of household labor in five European countries. Journal of Family Issues 34(12): 1623-1646. doi:10.1177/0192513X12464948.

Dominguez-Folgueras, M. and Castro-Martin, T. (2013). Cohabitation in Spain: No longer a marginal path to family formation. Journal of Marriage and Family 75(2): 422-437. doi:10.1111/jomf.12013.

Dronkers, J. and Härkönen, J. (2008). The intergenerational transmission of divorce in cross-national perspective: Results from the Fertility and Family Surveys. Population Studies 62(3): 273-288. doi:10.1080/00324720802320475.

Esping-Andersen, G. (1999). Social Foundations of Postindustrial Economies. Oxford: Oxford University Press. doi:10.1093/0198742002.001.0001.

Esteve, A., García-Román, J., and Lesthaeghe, R. (2012). The family context of cohabitation and single motherhood in Latin America. Population and Development Review 38(4): 707-727. doi:10.1111/j.1728-4457.2012.00533.x.

Farré, L. and Vella, F. (2013). The intergenerational transmission of gender role attitudes and its implications for female labour force participation. Economica 80(318): 219-247. doi:10.1111/ecca.12008.

Flaquer, L. (1998). Família i noves formes de convivència. Giner, S. (ed.). La societat catalana. Barcelona: Institut d'Estadística de Catalunya: 401-415.

Flaquer, L., Almeda, E., and Navarro-Varas, L. (2006). Monoparentalidad e infancia (Colección Estudios Sociales, 20). Barcelona: Obra Social La Caixa.

Flaquer, L. and Garriga, A. (2009). Marital disruption in Spain: Class selectivity and deterioration of economic conditions. In: Andreß, H.J. and Hummelsheim, D. (eds.). When Marriage Ends: Economic and Social Consequences of Partnership Dissolution. Cheltenham: Edward Elgar: 246-286. doi:10.4337/9781848447202. 00015.

Gabrielli, G. and Vignoli, D. (2013). The breaking-down of marriage in Italy: Trends and trendsetters. Population Review 52(1): 87-109. doi:10.1353/prv.2013.0005.

Garriga, A. (2010). Consequences of Parental Divorce and Family Structure on Children's Outcomes in European Societies: Individual, Cohort and Country Explanations. [PhD dissertation]. Barcelona: University Pompeu Fabra.

Goode, W.J. (1951). Economic factors and marital stability. American Sociological Review 16(6):802-812. doi:10.2307/2087507. 
Garriga, Sarasa \& Berta: Mother's educational level and single motherhood

Goode, W.J. (1993). World Changes in Divorce Patterns. New Haven, CT: Yale University Press.

Greene, W.H. (2012). Econometric Analysis (7th ed.). NJ, Upper Saddle River: Prentice Hall.

Härkönen, J. (2014). Diverging Destinies in International Perspective: Education, Family Structure, and Child Poverty in Europe and North America. [unpublished manuscript]. Stockholm: Stockholm University (working paper).

Härkönen, J. and Dronkers, J. (2006). Stability and change in the educational gradient of divorce. A comparison of seventeen countries. European Sociological Review 22(5): 501-517. doi:10.1093/esr/jcl011.

Iacovou, M. and Skew, A. (2010). Household structure in the EU. Essex: Institute for Social and Economic Research (ISER), University of Essex, (ISER working paper series, No. 2010-10).

Iacovou, M., Kaminska, O., and Levy, H. (2012). Using EU-SILC data for crossnational analysis: Strengths, problems and recommendations. Essex: Institute for Social and Economic Research (ISER), University of Essex, (ISER working paper series, No. 2012-03).

Istituto Nazionale di Stadistica, ISTAT (2010a). La vita quotidiana nel 2009. Indagine multiscopo annuale sulle famiglie "Aspetti della vita quotidiana" Anno 2009. Informazione -n. 5. Rome: Istituto nazionale di statistica.

Istituto Nazionale di Stadistica, ISTAT (2010b). La misurazione delle tipologie familiari nelle indagini di popolazione. Metodi e Normen. 46. Rome: Istituto nazionale di statistica.

Istituto Nazionale di Stadistica, ISTAT (2013). Gli stranieri al 15 censimento della popolazione. Rome: Istituto nazionale di statistica.

Jalovaara, M. (2001). Socio-economic status and divorce in first marriages in Finland 1991-93. Population Studies 55(2): 119-133. doi:10.1080/00324720127685.

Kearney, M.S. and Levine, P.B. (2012). Why is the teen birth rate in the United States so high and why does it matter? Cambridge, MA: National Bureau of Economic Research, (NBER working paper 17965).

Kennedy, S. and Thomson, E. (2010). Children's experiences of family disruption in Sweden: Differentials by parent education over three decades. Demographic Research 23(17): 479-508. doi:10.4054/DemRes.2010.23.17. 
Kiernan, K. (2004). Cohabitation and divorce across nations and generations. In: ChaseLansdale, P.L., Kiernan, K.E., and Friedman, R.J. (eds.). Human Development across Lives and Generations: The Potential for Change. New York: Cambridge University Press: 139-170.

Lesthaeghe, R. (1995). The second demographic transition in western countries: An interpretation. In: Mason, K.O. and Jensen, A.M. (eds.). Gender and Family Change in Industrialized Countries. Oxford: Clarendon Press: 17-62.

López-Menchero, J.M. (2003). El descenso de la fecundidad y sus implicaciones territoriales en España: 1975-2000. In: Escolano-Utrilla, S. and de la RivaFernández, J. (eds.). Despoblación y ordenación del territorio. Institución Fernando el Católico: 27-76.

Lyngstad, T.H. (2006). Why do couples with highly educated parents have higher divorce rates? European Sociological Review 22(1): 49-60. doi:10.1093/ esr/jci041.

Matysiak, A., Styrc, M., and Vignoli, D. (2014). The educational gradient in marital disruption: A meta-analysis of European research findings. Population Studies 68(2): 197-215. doi:10.1080/00324728.2013.856459.

McLanahan, S. (2004). Diverging destinies: How children are faring under the second demographic transition. Demography 41(4): 607-627. doi:10.1353/dem.2004. 0033.

McLanahan, S. and Percheski, C. (2008). Family structure and the reproduction of inequalities. Annual Review of Sociology 34(1): 257-276. doi:10.1146/annurev.soc.34.040507.134549.

Meggiolaro, S. and Ongaro, F. (2008). Repartnering after marital dissolution: Does context play a role? Demographic Research 19 (57): 1913-1934. doi:10.4054/ DemRes.2008.19.57.

Moen, P., Erickson, M.A., and Dempster-McClain, D. (1997). Their mother's daughters? The intergenerational transmission of gender attitudes in a world of changing roles. Journal of Marriage and the Family 59(2): 281-293. doi:10.2307/353470.

Moreno, L. and Marí-Klose, P. (2013). Youth, family change and welfare arrangements: Is the South still so different? European Societies 15(4): 493-513. doi:10.1080/14616696.2013.836400. 
Muñoz de Bustillo, R. and Antón J.A. (2010). De la España que emigra a la España que acoge: contexto, dimensión y características de la inmigración latinoamericana en España. America Latina Hoy 55: 15-39.

Musick, K. and Mare, R.D. (2006). Recent trends in the inheritance of poverty and family structure. Social Science Research 35(2): 471-499. doi:10.1016/j.ssre search.2004.11.006.

OECD (2014). OECD Family Database, Paris (www.oecd.org/social/ family/database.htm).

Oppenheimer, V.K. (1994). Women's rising employment and the future of the family in industrial societies. Population and Development Review 20(2): 293-342. doi:10.2307/2137521.

Oppenheimer, V.K. (1988). A theory of marriage timing. The American Journal of Sociology 94(3): 563-591. doi:10.1086/229030.

Pailhé, A., Mortelmans, D., Castro, T., Cortina-Trilla, C., Digoix, M., Festy, P., Krapf, S., Kreyenfeld, M., Lyssens-Danneboom,V., Martín-García, T., Rault, W., Thévenon, O., and Laurent Toulemo, L. (2014). Changes in the Life Course. A state of the art report. Families and Societies Working Paper Series \#6.

Part, K., Moreau, C., Donati, S., Gissler, M., Fronteira, I., and Karro, H. (2013). Teenage pregnancies in the European Union in the context of legislation and youth sexual and reproductive health services. Acta Obstet Gynecol Scand 92(12):1395-1406. doi:10.1111/aogs.12253.

Reher, D.S. (1998). Family ties in Western Europe: Persistent contrasts. Population and Development Review 24(2): 203-234. doi:10.2307/2807972.

Schröder, C. (2006). Cohabitation in Italy: Do parents matter? GENUS LXII(3-4): 5385.

Sigle-Rushton, W. and McLanahan, S. (2004). Father absence and child well-being: A critical review. In: Moynihan, D.P., Smeeding, T.M., and Rainwater, L. (eds.). The Future of the Family. New York, NY: Russell Sage Foundation: 116-159.

Smock, P.J., Manning, W.D., and Gupta, S. (1999). The effect of marriage and divorce on women's economic well-being. American Sociological Review 64(6): 794812. doi:10.2307/2657403.

Snyder, A.R., Brown, S.L., and Condo, E.P. (2004). Residential differences in family formation: The significance of cohabitation. Rural Sociology 69(2): 235-260. doi:10.1526/003601104323087598. 
Spanish Institute of Statistics (2011). http://www.ine.es

Spanish Institute of Statistics (2013a). http://www.ine.es

Spanish Institute of Statistics (2013b). http://www.ine.es

Treviño, R. (2006). Estructura y dinámica de la monoparentalidad en España [PhD thesis]. Barcelona: Universitat Autònoma de Barcelona.

Treviño, R. and Gumà, J. (2013). De la monoparentalidad a la reconstitución familiar: un análisis a partir de fuentes transversales. Revista de Sociología 98(2): 287309.

Williams, R. (2012). Using the margins command to estimate and interpret adjusted predictions and marginal effects. Stata Journal 12(2): 308-331. 
Garriga, Sarasa \& Berta: Mother’s educational level and single motherhood

\section{Appendix}

Table A1: Interactions between contextual variables (type of residential area and year of the survey) and mother's education. Logistic regressions for Spain and Italy (separated samples)

\begin{tabular}{|c|c|c|c|c|}
\hline & \multicolumn{2}{|c|}{ Spain } & \multicolumn{2}{|c|}{ Italy } \\
\hline & Model 1 & Model 2 & Model 1 & Model 2 \\
\hline & Coeff. & Coeff. & Coeff. & Coeff. \\
\hline \multicolumn{5}{|l|}{ Mother's education } \\
\hline Lower secondary education or less & Ref & Ref & Ref & Ref \\
\hline Upper secondary education & $-0.39 *$ & -0.18 & 0.10 & 0.20 \\
\hline Tertiary education & $-0.67^{\star \star \star}$ & $-0.64^{\star \star \star}$ & 0.23 & 0.22 \\
\hline \multicolumn{5}{|l|}{ Type of residential area } \\
\hline Densely populated area & Ref & Ref & Ref & Ref \\
\hline Intermediate area & $-0.36^{*}$ & $-0.30^{*}$ & -0.06 & -0.10 \\
\hline Thinly populated area & $-0.55^{\star \star}$ & $-0.37^{\star \star}$ & -0.07 & -0.05 \\
\hline Year of the survey: 2011 & -0.04 & -0.02 & $0.20^{* *}$ & $0.31^{*}$ \\
\hline \multicolumn{5}{|l|}{ Type of residential area* Mother's education } \\
\hline Intermediate area * Upper secondary education & 0.40 & & 0.01 & \\
\hline Thinly populated area * Upper secondary education & 0.35 & & 0.04 & \\
\hline Intermediate area * Tertiary education & -0.38 & & -0.30 & \\
\hline Thinly populated area * Tertiary education & $0.45+$ & & 0.02 & \\
\hline \multicolumn{5}{|l|}{ Year of the survey ${ }^{\star}$ Mother's education } \\
\hline 2011* Upper secondary education & & -0.07 & & -0.17 \\
\hline 2011 * Tertiary education & & 0.03 & & -0.17 \\
\hline $\mathrm{BIC}$ & 5054885.282 & 5066935.009 & 7510281.196 & 7510281.196 \\
\hline Constant & $-0.68^{*}$ & $-0.81^{\star \star}$ & $-1.66^{\star \star \star}$ & $-1.69^{\star \star \star}$ \\
\hline Pseudo r2 & 0.09 & 0.08 & 0.09 & 0.09 \\
\hline $\mathrm{N}$ & 7,798 & 7,798 & 10,802 & 10,802 \\
\hline
\end{tabular}

Note: The BIC of Model 2 of Table 4 with only main effects of covariates is $5067 \mathrm{e}+06$ for Spain $7513 \mathrm{e}+06$ Italy. Other estimates adjusted by all control variables in Model 2 of Table $4 .+p<0.10^{\star} p<0.05^{\star \star} p<0.01^{\star \star \star}<0.001$. 
Table A2: Interactions between contextual variables (regions) and mother's education. Logistic regressions for Spain and Italy (separated samples)

\begin{tabular}{|c|c|c|}
\hline & $\begin{array}{c}\text { Spain } \\
\text { Model } 1 \\
\text { Coeff. }\end{array}$ & $\begin{array}{c}\text { Italy } \\
\text { Model } 1 \\
\text { Coeff. }\end{array}$ \\
\hline \multicolumn{3}{|l|}{ Mother's education } \\
\hline Lower secondary education or less & Ref & Ref \\
\hline Upper secondary education & $-0.28^{\star}$ & -0.12 \\
\hline Tertiary education & $-1.17^{\star \star \star}$ & $-0.51+$ \\
\hline \multicolumn{3}{|l|}{ Spanish regions } \\
\hline Catalonia & Ref & \\
\hline Canary Islands & -0.13 & \\
\hline Asturias & -0.71 & \\
\hline Ceuta and Melilla & -0.21 & \\
\hline Cantabria & -0.60 & \\
\hline Extremadura & -0.05 & \\
\hline Balearic Islands & $-0.91+$ & \\
\hline Murcia & -0.21 & \\
\hline Galicia & -0.45 & \\
\hline Madrid & -0.35 & \\
\hline Navarra & -0.09 & \\
\hline La Rioja & -0.16 & \\
\hline Andalusia & -0.40 & \\
\hline Valencia & -0.44 & \\
\hline Castile and La Mancha & -0.32 & \\
\hline Basque Country & 0.04 & \\
\hline Castile and León & 0.37 & \\
\hline Aragón & 0.21 & \\
\hline \multicolumn{3}{|l|}{ Italian regions } \\
\hline Northwest & & Ref \\
\hline Northeast & & 0.00 \\
\hline Center & & -0.02 \\
\hline South & & -0.18 \\
\hline Islands & & $-0.90^{\star \star}$ \\
\hline \multicolumn{3}{|l|}{ Spanish regions ${ }^{\star}$ Mother's education } \\
\hline Canary Islands * Upper secondary education & 0.48 & \\
\hline
\end{tabular}


Garriga, Sarasa \& Berta: Mother’s educational level and single motherhood

Table A2: (Continued)

\begin{tabular}{|c|c|c|}
\hline & $\begin{array}{c}\text { Spain } \\
\text { Model } 1 \\
\text { Coeff. }\end{array}$ & $\begin{array}{c}\text { Italy } \\
\text { Model } 1 \\
\text { Coeff. }\end{array}$ \\
\hline Asturias * Upper secondary education & 1.04 & \\
\hline Ceuta and Melilla * Upper secondary education & -0.38 & \\
\hline Cantabria * Upper secondary education & -0.93 & \\
\hline Extremadura * Upper secondary education & -0.64 & \\
\hline Balearic Islands * Upper secondary education & 0.03 & \\
\hline Murcia * Upper secondary education & -0.41 & \\
\hline Galicia * Upper secondary education & -0.76 & \\
\hline Madrid * Upper secondary education & -0.11 & \\
\hline Navarra * Upper secondary education & 0.24 & \\
\hline La Rioja * Upper secondary education & 0.15 & \\
\hline Andalusia * Upper secondary education & 0.32 & \\
\hline Valencia * Upper secondary education & 0.47 & \\
\hline Castile and La Mancha* Upper secondary education & 0.29 & \\
\hline Basque Country * Upper secondary education & 0.48 & \\
\hline Castile and León * Upper secondary education & -1.04 & \\
\hline Aragón * Upper secondary education & -0.29 & \\
\hline Canary Islands * Tertiary education & 0.64 & \\
\hline Asturias * Tertiary education & 0.95 & \\
\hline Ceuta and Melilla * Tertiary education & 0.62 & \\
\hline Cantabria * Tertiary education & 0.29 & \\
\hline Extremadura * Tertiary education & -0.16 & \\
\hline Balearic Islands * Tertiary education & -0.82 & \\
\hline Murcia * Tertiary education & 0.48 & \\
\hline Galicia * Tertiary education & 0.60 & \\
\hline Madrid * Tertiary education & 0.30 & \\
\hline Navarra * Tertiary education & 1.57 & \\
\hline La Rioja * Tertiary education & 0.70 & \\
\hline Andalusia * Tertiary education & 0.53 & \\
\hline Valencia * Tertiary education & 0.93 & \\
\hline Castile and La Mancha* Tertiary education & 0.52 & \\
\hline Basque Country * Tertiary education & 0.42 & \\
\hline Castile and León * Tertiary education & 0.57 & \\
\hline Aragón * Tertiary education & 0.16 & \\
\hline
\end{tabular}


Table A2: (Continued)

\begin{tabular}{|c|c|c|}
\hline & $\begin{array}{c}\text { Spain } \\
\text { Model } 1 \\
\text { Coeff. }\end{array}$ & $\begin{array}{c}\text { Italy } \\
\text { Model } 1 \\
\text { Coeff. }\end{array}$ \\
\hline \multicolumn{3}{|l|}{ Italian regions ${ }^{\star}$ Mother's education } \\
\hline Northeast * Upper secondary education & & 0.24 \\
\hline Center * Upper secondary education & & 0.23 \\
\hline South * Upper secondary education & & 0.26 \\
\hline Islands * Upper secondary education & & 0.69 \\
\hline Northeast * Tertiary education & & 0.59 \\
\hline Center * Tertiary education & & $0.62+$ \\
\hline South * Tertiary education & & $0.93^{\star}$ \\
\hline Islands * Tertiary education & & $1.64^{\star *}$ \\
\hline $\mathrm{BIC}$ & 5042975.912 & 7487473.355 \\
\hline Constant & $-0.64+$ & $-1.43^{\star \star \star}$ \\
\hline Pseudo r2 & 0.09 & 0.09 \\
\hline $\mathrm{N}$ & 7,798 & 10,802 \\
\hline
\end{tabular}

Note: The BIC of Model 2 of Table 4 with only main effects of covariates is $5067 e+06$ for Spain $7513 e+06$ Italy. Other estimates adjusted by all control variables in Model 2 of Table $4 .+p<0.10 * p<0.05^{\star \star} p<0.01^{\star \star \star}<0.001$. 
Garriga, Sarasa \& Berta: Mother’s educational level and single motherhood

\section{Table A3: Interactions between mother's characteristics and mother's education. Logistic regressions for Spain and Italy (separated samples)}

\begin{tabular}{|c|c|c|c|c|c|c|}
\hline & \multicolumn{3}{|c|}{ Spain } & \multicolumn{3}{|c|}{ Italy } \\
\hline & $\begin{array}{l}\text { Model } 1 \\
\text { Coeff. }\end{array}$ & $\begin{array}{l}\text { Model } 2 \\
\text { Coeff. }\end{array}$ & $\begin{array}{l}\text { Model } 3 \\
\text { Coeff. }\end{array}$ & $\begin{array}{l}\text { Model } 1 \\
\text { Coeff. }\end{array}$ & $\begin{array}{l}\text { Model } 2 \\
\text { Coeff. }\end{array}$ & $\begin{array}{l}\text { Model } 3 \\
\text { Coeff. }\end{array}$ \\
\hline \multicolumn{7}{|l|}{ Mother's education } \\
\hline Lower secondary education or less & Ref & Ref & Ref & Ref & Ref & Ref \\
\hline Upper secondary education & -0.22 & -0.10 & -0.07 & 0.08 & 0.14 & $0.38^{\star \star}$ \\
\hline Tertiary education & $-0.61^{\star \star \star}$ & $-0.48^{\star \star \star}$ & $-0.31+$ & 0.13 & 0.10 & $0.42^{\star \star}$ \\
\hline \multicolumn{7}{|l|}{ Mothers' birth country } \\
\hline Country of residence & Ref & Ref & Ref & Ref & Ref & Ref \\
\hline European country & -0.03 & $-0.30^{\star}$ & $-0.29^{*}$ & 0.11 & 0.15 & -0.09 \\
\hline Non-European country & 0.24 & $-0.37^{\star \star}$ & $-0.37^{\star \star}$ & 0.15 & -0.25 & -0.04 \\
\hline Mother's marital status: never married & $1.68^{\star \star \star}$ & $2.01^{\star \star \star}$ & $1.67^{\star \star \star}$ & $1.91^{\star \star \star}$ & $2.02^{\star \star \star}$ & $1.92^{\star \star \star}$ \\
\hline Mother's age: younger than 40 & $-0.38^{\star \star \star}$ & $-0.40^{\star \star \star}$ & -0.13 & -0.45 & -0.45 & -0.04 \\
\hline \multicolumn{7}{|l|}{$\begin{array}{l}\text { Mothers' birth country * Mother's } \\
\text { education }\end{array}$} \\
\hline $\begin{array}{l}\text { European country* Upper secondary } \\
\text { education }\end{array}$ & -0.58 & & & 0.12 & & \\
\hline $\begin{array}{l}\text { Non-European country * Upper } \\
\text { secondary education }\end{array}$ & 0.08 & & & 0.15 & & \\
\hline European country * Tertiary education & -0.90 & & & -0.04 & & \\
\hline Non-European* Tertiary education & 0.08 & & & -0.03 & & \\
\hline \multicolumn{7}{|l|}{$\begin{array}{l}\text { Mother's marital status* Mother's } \\
\text { education }\end{array}$} \\
\hline $\begin{array}{l}\text { Never married * Upper secondary } \\
\text { education }\end{array}$ & & $-0.59+$ & & & -0.25 & \\
\hline Never married * Tertiary education & & $-0.69^{\star}$ & & & 0.07 & \\
\hline \multicolumn{7}{|l|}{ Mother's age* Mother's education } \\
\hline $\begin{array}{l}\text { Younger than } 40 \text { * Upper secondary } \\
\text { education }\end{array}$ & & & -0.31 & & & $-0.63^{\star \star}$ \\
\hline Younger than $40 *$ Tertiary education & & & $-0.69^{\star \star}$ & & & $-0.73^{\star \star}$ \\
\hline $\mathrm{BIC}$ & 5065113.310 & 5053877.617 & 5056425.840 & 7507551.773 & 7510430.231 & 7487224.288 \\
\hline Constant & $-0.81^{\star \star}$ & $-0.79^{\star \star}$ & $-0.81^{\star \star}$ & $-1.64^{\star \star \star}$ & $-1.64^{\star \star \star}$ & $-1.77^{\star \star \star}$ \\
\hline Pseudo r2 & 0.09 & 0.09 & 0.09 & 0.09 & 0.09 & 0.09 \\
\hline $\mathrm{N}$ & 7,798 & 7,798 & 7,798 & 10,802 & 10,802 & 10,802 \\
\hline
\end{tabular}

Note: The BIC of Model 2 of Table 4 with only main effects of covariates is $5067 \mathrm{e}+06$ for Spain $7513 \mathrm{e}+06$ Italy. Estimates adjusted by all control variables in Model 2 of Table $4 .+p<0.10{ }^{*} p<0.05^{* \star} p<0.01^{\star \star \star}<0.001$. 